NBER WORKING PAPER SERIES

\title{
DID VASCO DA GAMA MATTER FOR EUROPEAN MARKETS? TESTING FREDERICK LANE'S HYPOTHESES FIFTY YEARS LATER
}

\author{
Kevin H. O'Rourke \\ Jeffrey G. Williamson \\ Working Paper 11884 \\ http://www.nber.org/papers/w11884 \\ NATIONAL BUREAU OF ECONOMIC RESEARCH \\ 1050 Massachusetts Avenue \\ Cambridge, MA 02138 \\ December 2005
}

Bill Caferro, Greg Clark, Leonor Costa, Ivana Elbl, Giovanni Federico, Haggay Etkes, Ron Findlay, Avner Greif, Pedro Lains, Peter Lindert, Paolo Malanima, Anne McCants, John Munro, Peter Lindert, Şevket Pamuk, Jaime Reis, Sandra Sequeira, Nathan Sussman and Jan Luiten van Zanden all helped us with the evidence and argument, for which we are grateful. In addition, we gratefully acknowledge the comments received at the Medieval Global Economies Conference, University of Western Ontario, London, Canada (November 11-13, 2005). The project also benefited from the able research assistance of Katherine Johnson, Sibylle Lehmann, Ying Sun, Cristina Valverde and Darya Zhuk. Work on the paper started while O'Rourke was an IRCHSS Government of Ireland Senior Fellow, and he wishes to thank the Irish Research Council for the Humanities and Social Sciences for its generous financial support. Likewise, Williamson acknowledges generous financial support from the National Science Foundation and the Harvard Faculty of Arts and Sciences. The views expressed herein are those of the author(s) and do not necessarily reflect the views of the National Bureau of Economic Research.

(O2005 by Kevin H. O'Rourke and Jeffrey G. Williamson. All rights reserved. Short sections of text, not to exceed two paragraphs, may be quoted without explicit permission provided that full credit, including $\odot$ notice, is given to the source. 
Did Vasco da Gama Matter for European Markets? Testing Frederick Lane's Hypotheses Fifty Years Later

Kevin H. O'Rourke and Jeffrey G. Williamson

NBER Working Paper No. 11884

December 2005

JEL No. F14, N7

\begin{abstract}
$\underline{\text { ABSTRACT }}$
In his seminal publications between the 1930s and 1960s, Frederick Lane offered three hypotheses regarding the impact of the Voyages of Discovery that have guided debate ever since. First, pepper and other spice prices did not rise in European markets in the century before the 1490s, and thus could not have 'pulled in' the oceanic explorations by their rising scarcity. Second, Portuguese circumnavigation of Africa did not lower European spice prices across the $16^{\text {th }}$ century, implying that the discovery of the Cape route had no permanent effect on Euro-Asian market integration. Third, $15^{\text {th }}$ century Venetian spice markets were already well integrated with those in Iberia and northern Europe, implying that Portugal could not have had an intra-European market integrating influence in the $16^{\text {th }}$ century. Lane developed these influential hypotheses by relying heavily on nominal spice prices from Venice and the Levant. This paper revisits Lane's hypotheses by using instead relative spice prices, that is, accounting for inflation. It also draws on evidence from Iberia and northern Europe. In addition, it explores European market integration before and after 1503, the year when da Gama returned from his financially successful second voyage. Lane's three hypotheses are rejected: the impact of the Portuguese was profound on all fronts. We conclude by using a simple model of monopoly and oligopoly to decompose the sources of the Cape route's impact on European markets.

Kevin H. O'Rourke

Trinity College

Dublin 2

Ireland

and NBER

kevin.orourke@tcd.ie

Jeffrey G. Williamson

Department of Economics

216 Littauer Center

Harvard University

Cambridge, MA 02138

and NBER

jwilliam@fas.harvard.edu
\end{abstract}




\section{The Issues}

The 1490s have always been viewed as a turning point in European history. The leading names in accounts of the Age of Discovery are, of course, Columbus, who headed west across the Atlantic to discover the Americas, and da Gama, who headed east around Africa to discover the Cape route. Both men were looking for better access to Asian spice supplies. This paper explores the impact of their discoveries on international spice markets.

It was obvious to contemporary observers that the Portuguese explosion on to the Indian Ocean would have major economic and political consequences for Europe. News of the successful circumnavigation of Africa was greeted with alarm by Venice: according to Cairo’s Venetian ambassador it was a “causa de grande ruina del Stato Veneto,” (cited in Magalhães Godinho 1953: 283). Ever since 1503, however, scholars have increasingly downplayed the impact of the Cape route on the respective roles of Venice and Portugal in the European spice trade. In the late $20^{\text {th }}$ century, mainstream historians were arguing that “(t)he circumnavigation of the Cape of Good Hope did not strike an immediate death-blow to the Mediterranean spice trade” (Braudel 1972: 543), but rather that there was a recovery in the eastern Mediterranean's share of that trade, particularly after 1550 or so. This was a major theme of Frederic C. Lane (e.g. Lane 1933, 1940), and it was taken up later by Fernand Braudel (1972), Niels Steensgaard (1973) and others. By the late 1970s, this position had become so dominant that C. H. H. Wake (1979: 394) found it necessary to "re-affirm the reality of Portugal's dominance of the carrying trade between India and Europe and to reassess the economic and political significance of the Cape route in the sixteenth century.”

Lane relied heavily on various sorts of quantity data: Venetian involvement in the European carrying trade, the robustness of the Levant trade, the size of the Venetian merchant marine, the stability in the Venetian population, and so on. His focus on quantities 
is understandable. After all, relative market shares were crucial in determining the division of the profits arising from the spice trade, and profits were at the heart of the debate. Our focus in this paper is different since we are interested in the impact of the Cape route on European markets, European consumers, and European welfare. We have argued elsewhere that there is very little evidence that Euro-Asian commodity markets became more integrated prior to the $19^{\text {th }}$ century, or that declining inter-continental trade barriers, and thus price gaps, accounted for the European trade boom over the three centuries after 1492 and 1503 (O’Rourke and Williamson 2002). However, our evidence on price gaps used previously only dated from the 1580s, long after the initial voyages to the Americas and around the Cape. Our concern in this paper is not whether the Voyages of Discovery gave rise to a long run and continuous trend in world market integration over the centuries that followed, but rather whether these events had an immediate effect on European spice markets.

In order to explore such questions, we need to shift the focus away from quantities and towards prices, since it is only price behaviour that can provide conclusive evidence confirming or rejecting international commodity market integration. We are interested in whether da Gama and his successors brought European and Asian markets closer together. If they did, then Euro-Asian price gaps for trade goods such as pepper and fine spices should have declined, resulting (ceteris paribus) in lower relative prices of Asian trade goods in Europe, and, consequently, higher European consumer welfare. We are also interested in whether the shift to the Cape route integrated intra-European markets. If it did, then this should also have increased European welfare, by making its markets more efficient. Once again, prices should provide the evidence of an increased level of market integration or lack of it. Thus, we find ourselves in total disagreement with M. N. Pearson (1996: xxvii), who bemoans the "somewhat sterile debate over prices in the later $15^{\text {th }}$ century." On the contrary: 
without good price evidence, many of the most profound questions of cause and effect in this area can never be satisfactorily answered.

We are not the first to have explored the evolution of spice prices during the $15^{\text {th }}$ and $16^{\text {th }}$ centuries. Lane himself did so, particularly in his 1968 article focussing on Venice (Lane 1968), while, in a series of major works, Eliyahu Ashtor presented spice price data for Egypt and Syria as well as for Venice (Ashtor 1969, 1973, 1976). Our contributions are threefold. First, we exploit the efforts of previous generations of price historians by exploring price developments in as wide a range of European cities as possible. Second, we take seriously the possibility that $16^{\text {th }}$ century spice prices may have been driven as much by the after-effects of Columbus as by those of da Gama; that is, we want to correct explicitly for the fact that prices rose as American silver flowed into Iberia and the rest of Europe (Hamilton 1934; Fisher 1996). ${ }^{1}$ Third, we do not just explore price trends in particular markets, but price correlations between different markets.

In order to pursue this agenda, we need to take a position regarding when the Cape route should have started to influence European markets. ${ }^{2}$ In 1415, the Portuguese captured Ceuta, at the entrance to the Mediterranean; they colonized Madeira, $560 \mathrm{~km}$ west of

\footnotetext{
${ }^{1}$ De Vries (2003: 64) notes the importance of correcting for the general price level in considering $16^{\text {th }}$ century spice prices, while Ashtor (1973), when discussing the reasons why nominal spice prices fell in the Near East during the $15^{\text {th }}$ century, mentions a general falling price level as one possible cause. In an interesting contribution, Lybyer (1915: 585) comments on the fact that nominal pepper prices rose after 1520, remarking that wheat prices also rose during the period: "The fact is that pepper and other oriental wares rose with the general rise of prices in the 16th century, almost certainly caused by the addition to the European stock of gold and silver from the Americas. The evidence of price cannot be said to indicate disturbance from the Turkish conquest of Egypt; indeed it shows singularly little from the doubling of the Cape, which might be presumed to have caused a noticeable fall in prices.” But these remain rare exceptions to our characterization that this literature focuses on nominal prices alone.

${ }^{2}$ Maddison (2002: 52-65) and Phillips (1998: Chapter 12) provide accessible introductions to these well-known events.
} 
Morocco, during 1419-20. The Azores, almost 1500 km from Portugal, were settled in 1439, and the Cape Verde Islands in 1460. Further east on the African coast, São Tomé and Principe were settled in 1480. These settlements, and Portugal's strategic location on the Atlantic coast near the Mediterranean exit, gave the Portuguese special knowledge of sailing conditions in the Atlantic and halfway down the African coast. They had been exploiting that advantage for some time, but the big push took place in the late $15^{\text {th }}$ century. Diogo Cão (1482-1484) and Bartolomeu Dias (1487-1488) took preparatory voyages to explore the feasibility of a passage to India, the latter discovering that by first going west, faster winds got you east sooner. Meanwhile, Pero da Covilhã went overland to reconnoitre the west coast of India and the east coast of Africa. Thus, the Portuguese authorities were "well briefed on trading conditions in India and East Africa and the possibilities of navigation in the Atlantic before entrusting Vasco da Gama with a passage to India in 1497-1499” (Maddison 2002: 61). Da Gama’s first voyage was not a commercial success, but the knowledge gained helped push Pedro Cabral off (1500-1501), and his voyage was a bit more successful commercially. But da Gama’s second voyage (1502-1503) was the first big commercial success, returning with 1700 tons of spices, a figure that was about equal to Venetian annual imports in the late $15^{\text {th }}$ century (Maddison 2002: 63). ${ }^{3}$ In what follows, we take 1503 as the key transition date.

What impact did Portuguese discovery of the African Cape route have on European markets? Based on seminal publications on Venice between his 1933 American Historical Review and his 1968 Journal of Economic History articles, Frederick Lane offered several hypotheses that have guided debate on this issue in the half century or more since then.

\footnotetext{
${ }^{3}$ The African Cape route returned 1500 quintaux (100 kg) per annum in 1501-2, and almost 17,000 quintaux per annum in 1503-6, or 11 times as much (Magalhães-Godinho 1969: 701). One estimate has it that da Gama's second voyage made a 400 percent return on its investment. Of course, these voyages implied high risks as well as high returns. For example, "between 1500 and 1634, 28 percent of all ships that set out from Portugal bound for India were lost at sea” (Friedman 2005: 1213).
} 
First, Lane argued that pepper ${ }^{4}$ and other spice prices did not rise in European markets in the century before the 1490s:

"The opinion that spice prices rose in Europe in the century before 1492 ... is remarkably persistent ... A distinct drop, however, in the price of spices, and particularly of pepper, between the decades 1420-1430 and 1440-1450 is indicated [by the data]. Pepper prices fell about 50 percent in that interval and did not return to its former high level until after 1498.” (Lane 1968: 590)

This finding for Venice is mirrored by Ashtor’s $(1969,1973,1976)$ report that spice prices fell in the Near East during the $15^{\text {th }}$ century. This is an important finding, since prices provide useful evidence in trying to discriminate between two hypotheses which have been advanced to explain the Voyages of Discovery. In the words of A. H. Lybyer (1915: 577), "one of these holds in general that the advance of the Ottoman power gradually blocked the ancient traderoutes and forced a series of attempts to discover new routes ... The other view finds little or no connexion between the growth of Turkish power and the causes of the great discoveries: a set of motives quite independent of the rise of the Turks led men like Henry of Portugal and Christopher Columbus to explore the unknown world.” If Ottoman power blocked the traditional trade routes, prices should have risen in European relative to Asian markets, but Lane finds no evidence that this in fact happened.

If Lane's evidence could be generalized to the rest of Europe (as he suggested it can), it would mean that there was no pepper price boom to have triggered the Portuguese oceanic expansion. That is, it could not have been demand and rising scarcity pulling the Portuguese off on their voyages (perhaps "caused by the Turks having blocked the routes to the east" Lane 1963: 322), but rather it must have been research and development, accumulated

\footnotetext{
${ }^{4}$ Pepper was the dominate commodity in the spice trade. "In 1496, four galleys arrived in Venice from Alexandria with 2 million kilograms of spices, of which pepper was 1,363,934 ...” (Friedman 2005: 1215), or 68 percent.
} 
maritime knowledge, improved technology, institutional incentives, and investment by central authority that, on the supply side, eventually 'pushed' the Portuguese explorers around the Cape and in to the Indian Ocean spice market. As Lybyer comments, if there was no "marked influence upon prices exerted by the conquest of Constantinople by the Turks," then that event cannot have

"force(d) the western Europeans to seek new routes ... The entire hypothesis seems to be a legend of recent date, developed out of the catastrophic theory which made the fall of Constantinople an event of primary importance in the history of mankind. The great discoveries had their origin in a separate chain of causes, into which the influence of the Moslems of Spain, North Africa, and the Mameluke empire entered, but not that of the Ottoman Turks (Lybyer 1915: 583).”

Lane’s first hypothesis is driven by his observations on nominal pepper prices in Venice. However, Portuguese merchants and state authorities would have adjusted pepper prices by general price level changes, that is, they would have cared about relative prices. Furthermore, the Portuguese would have been most concerned about prices in Iberia itself, as well as in potential re-export markets in north-western Europe. ${ }^{5}$ They should have cared a lot less about prices in Venice or the Levant.

Second, Lane argued that Portuguese circumnavigation of Africa did not lower European spice prices across the $16^{\text {th }}$ century. On the contrary

“... the Portuguese were able to sell for prices higher than those the Venetians had received in the fifteenth century before Vasco da Gama rounded the Cape. After coming down to 52, prices rose so that the Portuguese were getting in Antwerp 66 percent more for their pepper in 1527 than in 1509. Portuguese circumnavigation of Africa did not lower the price of spices for Europeans; its immediate effect was rather to increase their costs.” (Lane 1968: 597)

\footnotetext{
${ }^{5}$ In his fascinating account of the genesis of the Voyages of Discovery, Magalhães-Godinho (1969: 553-555) notes that while English nominal pepper prices fell during the first half of the $15^{\text {th }}$ century before rising again, the price of salt continued to fall through the $1470 \mathrm{~s}$, implying that it was "plus intéressant de trafiquer avec le poivre qu'avec le sel. Mais tout cela est évidemment trop fragile pour fonder une véritable explication” (p. 555).
} 
Lane’s second hypothesis is supported by scholars such as C. R. Boxer (1991: 59) who states that prices increased "two- or even three-fold" during the late $16^{\text {th }}$ century. Like his first hypothesis, Lane's second is based on the behaviour of nominal prices, but, once again, it is relative prices that mattered. So, did the relative price of pepper and other spices rise or fall across the $16^{\text {th }}$ century after the Portuguese Cape route captured the spice trade? A lot rides on the answer. Since we know that the Cape route entailed lower transport costs compared with the overland routes through the Levant ("the Cape route [was] so decisively superior" Lane, 1963: 329), the fall in transport costs should, ceteris paribus, have lowered the relative price of spices in European markets after 1503. If instead it rose, as Lane argued, then there would be only three potential explanations for that behaviour: Portugal had a more effective monopoly after 1503 than did Venice before 1497; overseas spice supplies diminished after 1503 for some unrelated reason; or European demand for spices rose after 1503, again for some unrelated reason.

Third, although this was not a central focus of his work, Lane also argued that $15^{\text {th }}$ century Venetian spice markets were already well integrated with those in the Levant, Iberia, western Europe and central Europe. Regarding the integration of the spice market between Venice and the Levant, Lane states that "contemporaries saw a close connection between prices in the two markets” (Lane 1968: 590). Regarding the integration of the spice market between Venice and the rest of Europe, Lane states that declining "prices of pepper at Venice, 1363-1510 ... explains the fall in northern and western Europe” which he asserts occurred during the $15^{\text {th }}$ century (Lane 1968: 590).

If spice markets were already well integrated within Europe during the $15^{\text {th }}$ century, then there would have been little scope for the Portuguese discoveries to further integrate them. Yet, one might have thought that Lisbon's advantageous Atlantic location - placing the 
entrance of spice imports closer to the geographic centre of western and central European markets - would have served to lower the price spread across European locations, and to raise price correlations between them. Our competing hypothesis, then, is that Venice was sufficiently removed from the European core to have had much weaker integration effects on European markets, and that the quick rise of Lisbon around 1503 served to foster the integration of European markets for tradeables like pepper, as well as for fine spices, silk, cotton and other high value and low bulk Asian products not produced in Europe. Certainly European markets for goods such as pepper seem to have been well-integrated by the late $16^{\text {th }}$ century, by which time Braudel claims that "there was a single European pepper market" (Braudel 1972: 548). However, Braudel's discussion of this point deals only with $16^{\text {th }}$ century evidence, and cannot therefore address the issue of when this single market came into being. Lane’s third hypothesis and our competing alternative have never been tested with comprehensive price evidence.

This paper revisits these three hypotheses by using relative rather than nominal prices, that is, by deflating spice prices by the prices of grains such as wheat, "the outstanding product of the pre-industrial economies in Europe, and indeed their measure” (Braudel and Spooner 1966: 392). ${ }^{6}$ In addition, while Lane relied mainly on (relatively thin) price evidence from Venetian markets, this paper will rely instead on extensive $15^{\text {th }}$ and $16^{\text {th }}$ century commodity price information from Italy (Bassano del Grappa, Florence, Venice), Iberia (Andalusia, Barcelona, Navarre, New Castile, Old Castile, Valencia), western Europe (England, Belgium, the Netherlands), and central Europe (Austria, Germany, Poland).

\footnotetext{
${ }^{6}$ To check the robustness of our results, which use grain price deflators, we also used available CPI indices for Belgium and England. For these two countries, at least, our central findings are unaffected when CPI deflators are used, as the appendix shows.
} 
The plan of the paper is as follows. In section 2, we explore trends in pepper prices before and after 1503, to see whether the Voyages of Discovery had an impact on the relative price of pepper in European markets. Section 3 provides similar evidence regarding European markets for fine spices and incense, since there are a priori grounds for wondering whether what was true for pepper was necessarily true for other Asian imports such as cloves, cinnamon or ginger. Section 4 asks whether the shift from Venice to Lisbon helped speed the integration of European commodity markets, by looking at inter-regional price correlations before and after 1503. Section 5 asks when the Cape route influenced Asian as well as European markets, and Section 6 concludes.

\section{What Happened to Pepper Prices before and after da Gama?}

\section{Before da Gama}

Relying heavily on evidence from Venice, Lane’s first hypothesis was that pepper prices fell during the $15^{\text {th }}$ century, and thus could not have been a force that provoked the European search for cheaper Asian sources. ${ }^{7}$ Figure 1 plots his nominal prices, and, while very volatile, they clearly underwent a long run fall from the first quarter of the century to the last. Indeed, they fell from an average of 84.9 to 51.1 ducats per cargo between 1400-1425 and $1475-1500$, a 40 percent fall, or -0.07 percent per annum. This decline in nominal pepper prices in Venice also took place in Egypt and Syria, and Ashtor (1973: 38-43; 1976) explains the correlation in three ways. First, he documents an increase in the quantities supplied in Alexandria and Beyrouth. Second, he appeals to some fragmentary evidence suggesting that

\footnotetext{
${ }^{7}$ The reader should be assured that we are not attacking a straw man here. Lane's position that pepper prices fell across the $15^{\text {th }}$ century is held by many. For just two examples, see Ashtor (1983: 167-9, 313-15, 421-3 and 463) and the very recent survey by Friedman (2005: 1214).
} 
the price of spices in Yemen or even India may have fallen after the First Crusades. Third, he argues that the spice price decline could have reflected a more general deflationary trend in the Near East, as evidenced by falling grain prices (Ashtor 1969). Whatever the reason for falling spice prices in the Near East, it appears that the decline was transmitted to Venetian markets.

Was this decline transmitted to the rest of Europe as well? Surprisingly, the evidence in Figure 1 shows that pepper price trends in the rest of Europe failed to conform, at least in those four regions where pepper prices can be well documented. They rose steeply from midcentury in Austria (+1.5 percent per annum 1450-9 to 1490-9) and the Netherlands $(+1.1$ percent per annum 1450-9 to 1490-9), and for the full century for Belgium (+1.2 percent per annum 1400-9 to 1490-9). They were more stable in England, but still rose there over the full century (+0.4 percent per annum 1401-10 to 1491-1500). Table 1 (Panel A: nominal pre1503) summarizes these trends using regression analysis, where we can now use the more scattered Cracow evidence. We add a dummy variable for 1410-1414 (not reported in the table), since there was a very dramatic rise in Alexandrian, Damascan and Venetian pepper prices during those years, which was transmitted to other countries, and especially England, where, with a lag, prices remained abnormally high until 1414. With the exception of Cracow, every other European region outside Venice recorded a positive pepper price trend in the $15^{\text {th }}$ century, and even in the case of Cracow, the trend, while negative, was not statistically significantly different from zero. It appears that one cannot extrapolate from Venice to the rest of Europe, as Lane did.

Lane cites in support of his thesis some of the same data sources used here (Pribram for Austria, van der Wee for Belgium and Hamilton for Navarre), as well as Lybyer (1915: 580), who made use of the English data provided by J. E. Thorold Rogers (1866-1902) and of 
Vicomte d'Avenel's data for France. However, Table 1 shows nominal prices rose in Navarre, Belgium and Austria. ${ }^{8}$ As for the data in Lybyer, they show decadal English pepper prices in the $15^{\text {th }}$ century moving as follows: $12,32,16,13,9,13,14,14,17$, and 17 ; while the 25-year averages for France were as follows: 5, 3, 4.7, and 4. Once one accounts for the spike which occurred in 1410-14, even these nominal prices seem to trend up over the century as a whole, and certainly do so after 1450 .

Since the spike in pepper prices during 1410-14 seems to have misled Lane into thinking that there was a secular downward trend across the $15^{\text {th }}$ century, it's important to identify the causes of this dramatic one-off spike in prices. Was it something unique to pepper markets? Apparently not, since all spices underwent a similar price spike. Could it have been some European-wide monetary event? Apparently not, since no such price spike appears for grain and other products. Could it have been some European-wide demand shock? Ashtor (1969: 339) thinks so and blames “l'intensification de l'exportation en Italie.” Yet, it would have taken an extraordinary demand shock to have had such a dramatic continent-wide effect on prices. In our view, supply disruption between the Indies and the Middle East is the most plausible candidate, and the central force causing the disruption was most likely the great Chinese imperial armadas. ${ }^{9}$

Let us start by repeating the price narrative: English pepper prices increased 8 times between 1410 and 1411, averaged 2.6 times pre-1411 levels until 1414, were still 67 percent higher during 1415-22, and were still 45 percent higher during 1423-1427. Pepper prices finally recovered their pre-1411 levels after 1427 . With a few twists, a similar narrative

\footnotetext{
${ }^{8}$ Commenting on the Belgian data, Lane notes (1968: 590) that "(t)he decline appears when the prices in Brabant groats ... are converted into gold equivalents.” We agree that it is important to measure real (or relative) price trends, but disagree that gold prices provide such a measure.

${ }^{9}$ We thank Ron Findlay for this suggestion.
} 
applies to Belgium and Navarre. Now consider the correlation with Asian events. After all, this was a period when the new Ming emperor sent a huge armada into Southeast Asia and the Indian Ocean to extract tribute and to establish his legitimacy (Mote 2003; Rozario 2005). After Ming military might subdued Vietnam (1403-7), Java (1407), Burma (1409) and took the Malacca Straights, its leader, Admiral Zheng He, turned his huge armada and army on the Indian Ocean, invading Sri Lanka (1411) and intimidating the rulers of Calicut on the west coast of India. Between 1414 and 1422 three more expeditions were sent to the Indian Ocean, but only one more expedition was sent after 1422, and Zheng He died on it in 1433. Thus, any impact of Zheng He in deflecting pepper and other spices away from the Middle East and Europe would have taken place mainly between 1411 and 1422.

It is only a correlation, of course, but this exogenous Asian supply-side shock seems to offer the most likely explanation for the pepper price spike in the early $15^{\text {th }}$ century. According to Anthony Reid (1993: 12) these Ming voyages gave rise to "an enormous boost in the demand for Southeast Asian products," to such an extent that in his view the first Ming state trading mission of 1405 can be considered to mark the beginning of Southeast Asia's “age of commerce.” And it is certainly plausible to assume that a large increase in Chinese demand would translate into an enormous drop in exports to Europe, given the overwhelmingly dominant role of the Chinese market in the southeast Asian spice trade, a question which will be addressed at greater length later in this paper.

Once this temporary shock is accounted for, it is clear that in most of Europe pepper prices trended up, not down, over the course of the $15^{\text {th }}$ century. The sharp contrast between $15^{\text {th }}$ century Venetian and Arabian pepper price trends, on the one hand, and pepper price trends elsewhere in Europe, on the other, can have only two explanations. First, inflation rates may have differed across regions. Second, European commodity markets may have 
been poorly integrated even for "tradable" low bulk and high value luxuries, with the contrasting trends then being explained by rising intra-European transport costs, or by rising intra-European monopoly trading profits, or by more dramatic demand growth in the main European markets, or by all of these. Let us start with the first - different rates of inflation, while section 4 will deal with the second -- market integration and disintegration.

Each of our data sources also reports grain prices, a commodity which was immensely important to late medieval living standards, and would loom large in GDP accounts if we had them. As already mentioned, Ashtor, Braudel and other historians of the period regard grain prices as good indicators of the general price level, and thus we deflated our pepper price series by the available grain price series for each location (details are given in the Data Appendix). The relative price results are plotted in Figure 2. As can be seen, real pepper prices trended upwards in Austria and the Netherlands, as well as in England following the spike in prices in 1410-14. While there was no discernable upward price trend in Belgium or Navarre, there was no obvious downward trend there either. Table 1 (Panel B: real pre-1503) revisits the same evidence econometrically, calculating trends for the deflated or relative price of pepper, and confirming the impression given by Figure 2 . The upward trends for England, Austria and the Netherlands are confirmed, although the coefficient for the latter is not statistically significant at conventional levels. The trends for Belgium and Navarre are statistically indistinguishable from zero.

Sadly, we were unable to locate grain price data for Venice itself during this period, and so were unable to generate a Venetian real or relative pepper price series. However, even if we assume that Lane was right in his implicit assumption that what was true of nominal pepper prices in Venice must have been true of deflated or relative prices, we can safely 
conclude that the evidence does not support any generalization from this Venetian exception to the European continent as a whole. ${ }^{10}$

While Lane's assertion that pepper prices fell everywhere in $15^{\text {th }}$ century Europe must be rejected, there is no ubiquitous evidence of rising pepper prices everywhere either. Thus, the evidence may appear to favour the thesis that Portuguese exploration was driven by supply side events, not by rising demand, at least over the $15^{\text {th }}$ century as a whole. Yet, surely the Portuguese paid more attention to growing markets in northwest Europe, and surely they paid more attention to the price experience after 1450 than to that for the whole $15^{\text {th }}$ century? Figure 2 shows, and regressions (not reported here) confirm, that from 1450 onwards real pepper prices were rising in all regions for which we have evidence (England, Belgium, the Netherlands and Austria). It seems reasonable to assume that the Portuguese would not have had their eyes on Venetian markets, but rather on those northern markets, especially in the Low Countries and England. Thus, the price evidence suggests that from the mid-century onward, the incentives facing the Portuguese were in fact increasing as they attempted to wrest control over the pepper trade away from the Adriatic and towards the Atlantic.

\section{After da Gama}

Now consider Lane’s second hypothesis, that the Portuguese discovery and exploitation of the Cape route did not cause pepper prices to fall in the $16^{\text {th }}$ century. Figure 3 plots nominal pepper prices across the $16^{\text {th }}$ century, and they do indeed soar upwards everywhere in Europe (except, oddly enough, for poorly documented Italy). This visual impression is confirmed in Table 1 (Panel C: nominal post-1503): only two regions report a

${ }^{10}$ Of course, if Ashtor (1973) were right in his speculation that falling spice prices in the Near East were due to falling grain prices, then this would imply that real spice prices there were constant. 
fall in pepper prices, and these are both in Italy (the Venice series is very short and the Florence trend is statistically insignificant), while eleven show positive trends, and they are all highly significant. Lane was right on this score: nominal pepper prices did not fall in $16^{\text {th }}$ century Europe after da Gama, rather they rose. But recall that the Age of Discovery also involved Columbus, and that the subsequent importation of specie from the Americas had well-known inflationary consequences. Perhaps the rise in nominal pepper prices Lane observed, looking to the East, was simply a manifestation of European inflation generated by specie inflow, coming from the West.

Figure 4 confirms our suspicion about inflation, and thus rejects Lane’s second hypothesis. The deflated or relative price of pepper fell in Iberia - Andalusia, Old Castile, New Castile and Valencia; it fell in northwest Europe - Belgium, England and the Netherlands; it fell in central Europe - Austria and Germany; and it fell in Florence as well. Panel D of Table 1 confirms this impression econometrically: in every case, we find a statistically significant downward trend in the real price of pepper. These relative price trends are consistent with the conventional view that the Portuguese discoveries "opened up" trade with Asia, lowered transport costs between Europe and Asia, and thus caused the relative price of Asian goods to fall in $16^{\text {th }}$ century Europe. They also imply that the Cape route led to an increase in European consumer welfare and that the Portuguese had to share their gains with the rest of Europe. Finally, note that real pepper prices did not just fall in the immediate aftermath of the discovery of the Cape route, but continued to fall during the latter half of the $16^{\text {th }}$ century. The causes for this will be discussed in the concluding section of this paper. 


\section{So Goes Pepper, So Go Fine Spices?}

Pearson lists a number of ways in which pepper differed from other spices, such as cinnamon, cloves, ginger and nutmeg, or what he calls 'fine’ spices. First, “pepper far outranked all other spices as a trade item, and a product in everyday use” (Pearson 1996: xx). Second, "the areas growing the fine spices were extremely localized and hence easier for Europeans to control, whereas pepper production was more widely dispersed and so more difficult to oversee” (Pearson 1996: xxi; and see section 5 below). The latter comment suggests that it would be easier for the Portuguese to monopolize fine spice supplies, and hence extract larger monopoly rents from European consumers, than would be the case with pepper. If true, we may have been giving an excessively optimistic account of the impact of the Cape route on European consumers by focussing on pepper. Third, and on the other hand, Vitorino Magalhães-Godinho (1953: 105) pointed out that the rise in nominal prices of fine spices began after the rise in pepper prices, and he explained this lag by arguing that it was more difficult for the Portuguese to monopolize the fine spice trade, since fine spices were easier to smuggle than pepper, having a far higher value-to-weight ratio. ${ }^{11}$ If Pearson is right, the real pepper price trends might overstate the decline in the prices of other fine spices, while if Magalhães-Godinho is right, then the opposite would be true. Fourth, Wake (1979: 392-393) offers yet another reason for differentiating between pepper and fine spices: his figures show European pepper imports rising by just 27 percent during the $16^{\text {th }}$ century, as opposed to a 500 percent increase in imports of fine Moluccan spices between 1500 and 1620. Fifth, according to Ashtor (1969: 330) pepper was the trade item of primary interest to

\footnotetext{
${ }^{11}$ Besides, "le poivre vient du Malabar, où l'action portuguaise se fait sentir dès 1500 tandis que le girofle, le macis et la noix muscade viennent des îles de Malaisie, et la prise de Malacca n’a eu lieu qu'en 1511” (Magalhães-Godinho 1953: 105).
} 
the Portuguese in the Indian Ocean; they were less interested in the trade in other spices and Indian merchandise. Sixth, and finally, since pepper was a fairly common and cheap spice, and since it was consumed by many people other than the rich, its price elasticity of demand must have been a lot higher than was the case for the more expensive and luxury spices consumed by the rich alone. We will revisit this issue in Section 6 below.

Having established the importance of taking account of general price level trends, this section will focus on real (grain-deflated) spice prices only. Table 2 reports the results, Panel A dealing with pre-1503 trends, and Panel B dealing with post-1503 trends. The picture for the $15^{\text {th }}$ century is mixed. The prices of cardamom and cinnamon rose significantly, with average per annum cinnamon price increases of 1.5 percent in England and 2.3 percent in Austria. On the other hand, the price of cloves fell significantly in Belgium and Navarre, while the price of ginger fell significantly in England and Belgium. We confess that we have no good explanation for these contrasting trends, but note that ginger is often an exception to our general findings, and that Thorold Rogers commented more than a century ago on the unusual price behaviour of this particular spice: "for some reason or other it is not so markedly affected by ... political events” (Rogers 1866-1902, Volume 4: 662).

However, there is no ambiguity regarding the post-1503 trends: barring the puzzling exception of cloves in Andalusia, real prices fell significantly in every single case. The post1503 pepper price decline was thus accompanied by price falls for spices more generally, implying even greater welfare gains for European consumers. Indeed, the average price decline for fine spices (1.3 percent per annum) was a bit higher than that for pepper (0.9 percent per annum), although we would not want to make too much of the difference given the quality of the data at our disposal. We can safely conclude, however, that pepper was not an isolated exception, and that the opening of the Cape route was followed by a dramatic 
decline in the cost of Asian spices in Europe, which once again continued for the remainder of the century.

There is, of course, a competing demand-led explanation for these $16^{\text {th }}$ century price declines. That is, could not the secular rise and fall in the relative price of pepper and fine spices have been driven by faster European income growth in the $15^{\text {th }}$ compared to the $16^{\text {th }}$ century? In an earlier paper, we estimated that Europe’s "surplus income” hardly grew at all across the $16^{\text {th }}$ century (O’Rourke and Williamson 2002: 435), while it must have grown much faster, at least in per capita terms, during the $15^{\text {th }}$ century in the wake of the Black Death. So, could this postulated demand growth have accounted for the rise and fall in the relative price of luxury spices? The answer is no. This otherwise plausible competitor is rejected when we recall that European spice imports grew very fast in the $16^{\text {th }}$ century, which is inconsistent with the hypothesis that falling prices were due to an inward shift in the demand curve. Thus, we think that the discovery of the Cape route accounts for the historical facts far better.

\section{European Pepper and Fine Spice Market Integration before and after da Gama}

The third hypothesis which we wish to explore is that $15^{\text {th }}$ century Venetian spice markets were well integrated with those in the rest of Europe, implying that the Portuguese discovery could not have helped to integrate the European market for tradeables, since the Venetians had already done so. There are two reasons why we think this inference is inappropriate. First, Venice was tucked away in what was to become the backwater of early modern Europe, while Lisbon was centrally located on the Atlantic coast, close to the leading west European economies, and right near the Mediterranean exit. Surely Asian imports entering $16^{\text {th }}$ century Lisbon (and, later, Amsterdam) had a more powerful impact on 
integrating European markets for these tradeables than did $15^{\text {th }}$ century Venice. Second, the Venetians and the Portuguese organized their re-exports of Asian luxury goods in very different ways, and these differences must have mattered (Braudel 1985: 125, 149). The Venetians prevented their own merchants from trading directly in Germany, which meant that Germans wishing to obtain spices, silk and other luxury goods had to make the journey to Venice, where they were obliged to stay in the Fondaco dei Tedeschi, and buy and sell under the supervision of the Venetian government. By contrast, the Portuguese shipped their goods directly to Antwerp: the first Portuguese spice ship arrived there in 1501, and in 1508 the king founded the Feitoria de Flandres, charged with the trade to the Low Countries. Why the difference between the policies? In part this was because the Portuguese, unlike the Venetians, were expending considerable resources to obtain the spices directly in Asia, and were not able to cope with the additional task of organizing the distribution of spices within Europe as well. In part it was also simply because the northern and central European market for pepper and spices was large, and probably the fastest growing one. Under the Portuguese hegemony, German, Hansa and English merchants could make the relatively easy trip to Antwerp to exchange copper, silver, woollen cloth or other items for Asian trade goods. Under the Venetian hegemony, those goods had to cross the Alpine passes before continuing on their journey south or north. While the Portuguese eventually closed the Feitoria in 1549, by then the Venetians had begun to regain some of their previous market share, and European consumers found themselves in a market with more than one major supplier (Braudel, ibid.). Surely these changes must have enhanced market integration within Europe, and surely the European consumer gained as a consequence.

Our alternative hypothesis is thus that $16^{\text {th }}$ century European pepper markets became far better integrated than those in the $15^{\text {th }}$ century. We have already seen some hints that this 
alternative hypothesis might fit the facts better when contrasting the behaviour of $15^{\text {th }}$ century Venetian and Arabian pepper prices, on the one hand, and pepper prices in the rest of Europe, on the other. The fact that pepper prices were declining in the chief supplying markets, but rising in the chief importing markets, hardly suggests a competitive and well-integrated market.

We test these competing hypotheses by looking at pair-wise price correlations between regional markets. Table 3 presents these time series correlations between all regions for which we have real pepper prices. For the pre-1503 period, the sample includes Austria, Belgium, England, Navarre, and the Netherlands. For the post-1503 period, the sample loses Navarre but gains Andalusia, Old Castille, New Castille, Florence, Munich and Vienna. The table highlights in bold the four regions for which we have overlapping data before and after 1503, where comparison between the two periods is possible. The data offer some prior reassurance of their quality since regions which were closer together had much tighter price correlations before 1503 than regions farther apart, evidence consistent with the recent and impressive work by Wolfgang Keller and Carol Shiue (2004) comparing $18^{\text {th }}$ and $19^{\text {th }}$ century commodity markets in Europe and China. In particular, while contiguous Belgian and Dutch markets were very tightly correlated with each other (with a correlation coefficient of 0.67 ), and while they were both well correlated with nearby English markets (with correlation coefficients of 0.50 and 0.56), they were poorly correlated with markets in distant Austria (the correlation coefficient was 0.32 for the Belgium-Austria pair, and just 0.09 for the Netherlands-Austria pair). Similarly, English markets were much less well correlated with Austrian and Navarre markets (both correlation coefficients are less than 0.3) than they were with the Low Countries. 
The pre-1503 correlations stand in sharp contrast with those of the post-1503 period. In every case where it is possible to make a bilateral comparison, the correlation coefficient increased after 1503. Where markets were already very well-integrated, such as between Belgium and Holland, the increases were small; but in markets which had been more peripheral in the $15^{\text {th }}$ century, the increases were quite substantial. Thus, the Belgian-Austrian correlation coefficient increased from 0.32 to 0.51 , the Dutch-Austrian coefficient increased from 0.09 to 0.63 , and the English-Austrian coefficient increased from 0.29 to 0.55 . With one or two exceptions (such as the low figures for Andalusia and New Castile), Panel B of Table 3 suggests relatively well-integrated European pepper markets after da Gama. To this extent, our alternative hypothesis does better than Lane's: the evidence is not consistent with his view that markets were already well-integrated during the $15^{\text {th }}$ century, and thus that the Portuguese could not have improved market integration by a lot. On the contrary, European market integration improved considerably after 1503, suggesting that Lisbon's (at least partial) displacement of Venice had much to do with it. True, there may have been other forces at work that might account for this improved European market integration, but the Portuguese discoveries certainly seem to be one particularly plausible candidate.

Table 4 carries the analysis further, by presenting similar correlation coefficients for those fine spices for which data are available both before and after 1503. Panel A gives the data for cloves, and the results are qualitatively the same as for pepper: correlations between real clove prices in different regions were much higher after 1503 than before. Thus, the English-Belgian correlation increased from 0.41 to 0.73 ; the English-Austrian correlation increased from minus 0.08 to plus 0.69 ; and the Belgian-Austrian correlation increased from 0.07 to 0.75 . With the puzzling exception of Andalusia (again), ${ }^{12}$ all bilateral market pairs

\footnotetext{
${ }^{12}$ The Andalusian exception is clearly related to the fact that it is the only price series in Table 2 displaying a downward trend after 1503.
} 
exhibited a high degree of inter-correlation after the Voyages of Discovery. Similarly, real cinnamon prices in England were more highly correlated with those in Belgium and Austria after 1503 than before, although the Austrian-Belgian correlation declined (Panel B, 0.47 to 0.19). Panel C shows that ginger was, for some reason, an exception to the general rule of increased market integration across these two centuries, with English prices becoming much less correlated with Austrian and Belgian prices; again, the Belgian-Austrian pair was an exception, this time exhibiting a higher correlation in the later period. We have no explanation for the puzzling difference between ginger and all other spices, although Wake (1979: 381) notes that “(g)inger remained the major item in the much reduced Levantine trade” during the $16^{\text {th }}$ century, and that as the century progressed, "ginger was gradually displaced in the Portuguese private trade by a growing volume of the more expensive spices and associated goods.” To this extent, the declining price correlations for ginger are perhaps not inconsistent with our argument that it was the Portuguese who served to integrate European markets for other spices. Be that as it may, the fact remains that for the nine possible inter-temporal bilateral price correlations reported in Table 4, six show rising price correlations, while only three show declines, two of which are for ginger.

On balance, therefore, our conclusion is that the Portuguese did not just bring European and Asian markets closer together, with subsequent benefits to European consumers. They also brought European markets closer to each other, which implied further welfare gains for the European economy.

\section{The Cape Route, European Markets and Asian Markets}

What, if any, were the effects of the Cape route on Asian markets? In a recent survey article, John Wills (1993) summarizes the voluminous literature that has emerged in recent 
decades on the early modern history of 'maritime' Asia. One of the key themes of this literature is that “(w)here previously even Asian nationalist scholars saw a rapid shift to European dominance of the seas in the "Vasco da Gama epoch," and saw the Asians largely as passive victims, today's historians see that participants in the maritime history of every part of Asia included Asian navigators, merchants, pirates, investors, and merchant-princes, and that these Asian participants remained effective competitors of the Europeans far longer than earlier scholars had thought” (Wills 1993: 83).

In terms of this paper's focus, the central point is that European demand only accounted for a small share of Asian spice production in the late $15^{\text {th }}$ and early $16^{\text {th }}$ centuries. Its share might have risen since Marco Polo’s day, when according to the great explorer a hundred spice ships docked in Quanzhou for every Italian vessel arriving in Alexandria (quoted in Reid 1993: 12); but nonetheless it remained small. According to Reid (1993: 19), over the $15^{\text {th }}$ century Europe's share of Malukan spices rose only modestly, from less than a tenth to roughly a fourth. Pearson's assessment (1996: xxiii) is that in "the fifteenth century and later, most Asian spices were consumed by Asians. India consumed twice as many fine spices as Europe. Of total Asian spice production in 1500, Europe took at most one quarter. China was a huge consumer of pepper, taking around 75\% of total southeast Asian production.” An earlier estimate by Jan Kieniewicz implied that a similar share of Malabar pepper went to places other than Europe. According to him, only about 30 percent of Malabar production in 1515 went to Lisbon (Kieniewicz 1969: 63), the remaining 70 percent absorbed by Asia - north to the Mughals, east to the rest of the Indian Ocean, and west to the Levant. He also estimated that only 55 percent of the Malabar production shipped west between 1504 and 1549 actually went to Lisbon, the rest going to the Levant, only a portion of which moved on to Europe. Furthermore, while European consumption rose during the $16^{\text {th }}$ century, 
so did Asian production: indeed, pepper supplies in Malabar rose by 7 or 8 percent per annum between 1515 and 1607 . Yet, Kieniewicz believed that this supply was driven by a "growing demand for pepper in India, China, Persia and the countries ruled by the Ottoman Empire” and that European demand had nothing to do with it (Kieniewicz 1969: 61-62). As a consequence, European consumption still only accounted for about 25 percent of total Asian production in 1600 (Pearson 1996: xxviii). ${ }^{13}$ A. R. Disney (1978: 36) offered even lower figures, arguing that the Portuguese only transported about 10 percent of total southwest Indian pepper production to Lisbon in the early $17^{\text {th }}$ century, with most of the remainder being consumed in India. Of course, Malabar wasn’t the only source of pepper: one estimate has it that in 1515 only 48 percent of Asian pepper production was in Malabar, with another 47 percent in North Sumatra, and the remaining 5 percent in west Java and the Malayan peninsula (Bulbeck et al. 1998: 62). Southeast Asia found its major source of demand in China (75 percent: see above). Finally, perhaps the evolution of the role of European demand in Asian spice markets can be seen best by cloves, since it was only grown in Malaku (Southeast Asia). European imports accounted for the following percentage share of Malaku production: 1400-1409 14 percent, 1510-1519 7.2 percent, 1570-1579 17 percent, and 1610161952 percent (Bulbeck et al. 1998: 54). We conclude that European demand had only a trivial impact on Asian spice prices until the late $16^{\text {th }}$ and early $17^{\text {th }}$ century, a position now supported by many specialists (Friedman 2005: 1213; Bautier 1971: 142; Spufford 2003: 309-13).

In theory, the fall in transport costs between Europe and Asia should have led to both the European price decline which we have documented, and to an Asian price increase. In theory, that is. In practice, however, the fact that the European market was still relatively

\footnotetext{
${ }^{13}$ According to Boxer (1991: 59), both European consumption and Asian production roughly doubled over the second half of the $16^{\text {th }}$ century.
} 
small suggests that Asian pepper and fine spice prices were primarily set in Asia. The Cape route, Portuguese efforts to monopolize the Euro-Asian trade, and counter-efforts by the Turks, Venetians and others to break this monopoly, would all have affected the price markup over Asian prices which European consumers would have had to bear. But those events should not have had any great impact on prices facing Asian consumers and producers. Indeed, to the extent that Europeans managed to influence Asian prices at all, they are likely to have done so in the 'wrong' direction: that is, if they really did exercise some monopsony power, they would have driven Asian prices downwards.

Even here, however, the ability of the Europeans to accomplish their goals were mixed. Portuguese attempts to enforce a monopoly in the Indian Ocean were never really successful, due to lack of manpower and resources, and other factors such as the need to maintain good relations with Persia, which was an essential counterweight to the Ottoman Empire (Boxer 1991: 59; Braudel 1972: 546). East of Malacca, they met with even less success, having been defeated by Chinese coastguard fleets in 1521 and 1522 (Boxer 1991: 49). In India, they did not buy pepper directly from growers, but from Hindu, Muslim and Christian middlemen, who themselves were able to extract some of the available profits to be made from the pepper trade (Disney 1978: 35). Controlling supply was obviously easier than controlling trade on a vast ocean, at least when the sources of supply were geographically limited. However, C. R. de Silva shows how, even though the Portuguese declared a royal monopoly on the clove trade in 1522, and succeeded in dominating the Moluccas by 1533, in fact their efforts to maintain the monopoly were beset with difficulties, and "when they relinquished control they had not made any significant impact on either the volume or the organization of the trade” (de Silva 1988: 258).${ }^{14}$ On the other hand, he also shows that the

\footnotetext{
${ }^{14}$ Chaudhuri's (1985: 75) summary judgement is that "there was never any question as to the Portuguese monopoly in the Moluccan spice trade," owing both to successful local efforts to
} 
margin between prices realized for cinnamon in Calicut and Goa, on the one hand, and the prices paid to cinnamon peelers in Ceylon, on the other, rose in the early $17^{\text {th }}$ century (de Silva 1989: 37-8).

To venture any further into such territory would pull us away from the central focus of this paper, so we will stop here and simply repeat the methodological point of this article: the true test of whether or nor European traders succeeded in their attempts to extort monopsony profits from Asian producers and monopoly profits from European consumers will lie in suitably deflated price data, ${ }^{15}$ not in the scattered data on quantities, qualitative evidence on smuggling, documentation on the spread of production and so on, all of which characterizes so much of the traditional literature on the topic.

\section{Monopoly, Oligopoly, Trading Profits and the European Consumer}

The Portuguese discovery of the African Cape route would eventually have historic geopolitical implications, but its immediate economic impact on Europe has often been denied. For example, Niels Steensgaard (1973: 154) has written that the establishment of the Estado da India "led to no structural changes in the Asian trade," and that "(t)he Portuguese carracks did not obtain any great significance as a connecting link between Europe and Asia.” We argue that by focussing on quantity evidence, and on market shares, economic historians have been looking in the wrong place. While correlation cannot prove causation, the real or relative price of spices rose in most of Europe (outside of Venice) prior to 1503, and fell everywhere in Europe afterwards. Furthermore, price integration between European

keep exporting themselves, and to private Portuguese emulation of this behavior.

${ }^{15}$ For an example, see Disney’s (1978: 39) statements about Portuguese attempts to hold down supply prices in the late $16^{\text {th }}$ century, "at a time of general inflation.” More systematic evidence of this sort is what is required, in our view. 
markets seems to have increased significantly between the $15^{\text {th }}$ and $16^{\text {th }}$ centuries. It is certainly true that, as Boxer (1969: 415) puts it, “(n)o reputable historian nowadays maintains that the Portuguese $16^{\text {th }}$ - century thalassocracy in the Indian Ocean was always and everywhere completely effective,” or that Venice never recovered a substantial share of the market in the late $16^{\text {th }}$ century. However, this is to miss the more important and systemic economic point: the Cape route permanently altered the competitive structure of the European import trade from Asia, and all the more so if Boxer is correct.

Figure 5 makes the argument using standard microeconomic tools. The top figure shows equilibrium in the European market, assuming that it is supplied by a monopolist. The figure assumes that the monopolist buys spices in the Asian market at an exogenous price $\mathrm{p}^{*}$, which is determined by demand and supply in Asia and is unaffected by European demand. The fixed marginal cost facing the monopolist is then $\mathrm{p}^{*}+\mathrm{t}_{0}$, where $\mathrm{t}_{0}$ is the initial cost of transporting a unit of spices from Asia to Europe across the traditional middle-eastern routes. As usual, the monopolist will maximize profits by equating marginal cost with marginal revenue (given by the MR schedule, derived, of course, from the European demand curve, D): the equilibrium is then given by $\mathrm{A}$, with an initial European price $\mathrm{p}_{0}$ and an initial import quantity $\mathrm{Q}_{0} \cdot{ }^{16}$

Now let the discovery of the Cape route lower transport costs to $t_{1}$. If the route remains in monopoly hands - for example, if the Portuguese completely displace Venice then we move to a new equilibrium B, involving a lower European import price $\mathrm{p}_{1}$, and a higher European import quantity $\mathrm{Q}_{1}$. European consumers gain in this new equilibrium since prices are lower, with their consumer surplus rising from $\mathrm{DAp}_{0}$ to $\mathrm{DBp}_{1}$. However,

\footnotetext{
${ }^{16}$ Figure 5 takes the demand curve to be fairly elastic, as we assume it was for pepper. In contrast, the demand curves for 'fine' spices would have been more inelastic, implying that the mark up from the Asian to European price would have been much bigger for the latter.
} 
consumers do not appropriate all the benefits of the Cape route under this scenario, since prices fall $\left(\mathrm{p}_{0}-\mathrm{p}_{1}\right)$ by less than the decline in transport costs $\left(\mathrm{t}_{0}-\mathrm{t}_{1}\right)$; thus, the Portuguese also appropriate some of the benefits, with their profits $\mathrm{p}_{1} \mathrm{BF}\left(\mathrm{p}^{*}+\mathrm{t}_{1}\right)$ exceeding the initial Venetian profits $\mathrm{p}_{0} \mathrm{AE}\left(\mathrm{p}^{*}+\mathrm{t}_{0}\right)$.

What traditional historians have shown, however, is that the Portuguese did not succeed in their ambitions to monopolize the Asian spice trade, by choking off the supply of spices reaching the Mediterranean via traditional Levant outlets such as Alexandria and Beirut. This is what Steensgaard and others have in mind when they speak of the Cape route not changing the structure of the spice trade in any fundamental sense. However, the lower panel of Figure 5 shows that the very fact that the Venetians maintained a share of the spice trade, especially after 1550 or so, served to augment the impact of the Cape route, rather than diminish it. As we have seen, if the Portuguese had succeeded in monopolizing the trade, imports would have increased from $\mathrm{Q}_{0}$ to $\mathrm{Q}_{1}$, with a consequent decline in prices, an increase in European consumer welfare, and an increase in trading profits. This might well have been the situation, roughly speaking, in the second decade of the $16^{\text {th }}$ century. But now imagine that the overland Levant route started to function again, with the same level of transport costs associated with it as before $\left(\mathrm{t}_{0}\right)$. There would now be two suppliers in the European market, not one, and market equilibrium would now be determined by the familiar Cournot oligopoly model illustrated in Panel B. ${ }^{17}$

Since Venetian transport costs are unchanged from their initial level, their reaction function is given by $\mathrm{RF}_{\text {Venice }}$, and intersects the vertical axis (along which Venetian imports are measured) at $\mathrm{Q}_{0}$. The Portuguese reaction function is given by $\mathrm{RF}_{\text {Portugal }}$, and since the Portuguese can use the cheaper Cape route, it lies further away from the origin than does the

\footnotetext{
${ }^{17}$ Irwin (1991) makes a compelling case as to why this model is the correct one for thinking
} about oligopolistic long-distance trade in the early modern period. 
Venetian one, intersecting the horizontal axis (along which Portuguese imports are measured) at $\mathrm{Q}_{1}$. In this model, equilibrium is given by $\mathrm{C}$, which involves a higher level of aggregate imports than either $\mathrm{Q}_{0}$ or $\mathrm{Q}_{1}$, and thus lower prices and higher levels of consumer welfare (as indicated in the upper part of the diagram).

Figure 5 allows us to analyse various alternative scenarios with comparative ease. For example, if the Europeans succeeded in lowering Asian supply prices $\mathrm{p}^{*}$ through the exercise of monopsony power, this would lead to both reaction functions shifting outward, and to higher levels of imports and lower prices. The only way that such a development would not lower European prices would be if, simultaneously, the import trade in Europe were monopolized, and something like this did indeed happen in the $17^{\text {th }}$ century when the Dutch grabbed control of both production and trade in cloves. More relevant in terms of the $16^{\text {th }}$ century experience, imagine that the Portuguese succeeded in raising trading costs along the traditional Red Sea and Persian Gulf routes, without abolishing these altogether. In this case, the marginal costs facing the Venetians would increase. If they were monopolists, this would lead to a lower desired level of imports (Panel A), and this in turn implies that their reaction function in Panel B would shift inwards, leading to a new equilibrium such as G, with lower levels of total imports, higher prices, lower welfare for European consumers, but higher trading profits for the Portuguese. If Portugal was able to raise trading costs along the overland Levant route to a high enough level, a Portuguese monopoly would result, with an equilibrium at $\mathrm{Q}_{1}$. The diagram makes it clear that Portuguese attempts to block traditional Levant trade routes would indeed raise European prices, but only relative to a situation of unfettered competition between the two routes. Successful attempts to block the route would not, however, have raised prices relative to their $15^{\text {th }}$ century levels. At worst, they could raise them to $\mathrm{p}_{1}$, but this is lower than the initial price level $\mathrm{p}_{0}$. 
Therefore, it is not surprising that the Cape route led to falling European spice prices. It had this effect for two reasons. First, there was an inherent transport efficiency advantage to using the Cape route, which would only be permanently undermined in the late $19^{\text {th }}$ century by the combination of steamships and the Suez Canal. This led to a decline in prices corresponding to a shift in equilibrium from A to B in Figure 5, which we think occurred during the first two decades of the $16^{\text {th }}$ century, when no Malukan spices reached Italy via the traditional Middle Eastern route (Reid 1993: 14). Second, the Voyages of Discovery permanently altered the structure of trade between Europe and Asia. While Venice managed to regain a substantial market share in the late $16^{\text {th }}$ century, it never succeeded in abolishing or even suppressing the Cape route, nor could it ever have done so. The result was a more competitive Euro-Asian trading market, with European consumers the ultimate beneficiaries; this effect is illustrated by the shift from B to C in Figure 5, and is the reason why in our view prices continued to fall in the late $16^{\text {th }}$ century. In the $17^{\text {th }}$ century, Anglo-Dutch competition on the Cape route would further drive down pepper prices and drive up European consumption and welfare (while for products such as cloves, where the Dutch managed to monopolize supply, prices remained high) (Wake 1979: 391-2). However, these procompetitive effects were already benefiting European consumers during the 'Portuguese' $16^{\text {th }}$ century. 


\section{References}

E. Ashtor (1969), Histoire des Prix et des Salaires Dans l'Orient Médiéval (Paris: S.E.V.P.E.N.).

E. Ashtor (1973), “La découverte de la voie maritime aux Indes et les prix épices,” in Mélanges en l'honneur de Fernand Braudel, Volume I (Toulouse 1973).

E. Ashtor (1976), “Spice Prices in the Near East in the $15^{\text {th }}$ Century," Journal of the Royal Asiatic Society 1: 26-41. Reprinted in M.N. Pearson (ed.), Spices in the Indian Ocean World (Gateshead: Variorum).

E. Ashtor (1983), Levant Trade in the Later Middle Ages (Princeton, N.J.: Princeton University Press).

R. H. Bautier (1971), The Economic Development of Medieval Europe, trans. H. Karolyi (New York: Harcourt Brace Jovanovich).

C. R. Boxer (1969), “A Note on Portuguese Reactions to the Revival of the Red Sea Spice Trade and the Rise of Atjeh, 1540-1600,” Journal of Southeast Asian History 10: 415428. Reprinted in M.N. Pearson (ed.), Spices in the Indian Ocean World (Gateshead: Variorum).

C. R. Boxer (1991), The Portuguese Seaborne Empire 1415-1825 (Carcanet; first edition 1969, London: Hutchinson).

F. Braudel (1972), The Mediterranean and the Mediterranean World in the Age of Philip II, Vol. I (London: Collins).

F. Braudel (1985), Civilization and Capitalism 15th-18th Century, Volume III: The Perspective of the World (London: Fontana). 
F. Braudel and F. Spooner, 'Prices in Europe from 1450 to 1750,” Chapter VII in E. E. Rich and C. H. Wilson (eds.), The Cambridge Economic History of Europe: Volume IV: The Economy of Expanding Europe in the Sixteenth and Seventeenth Centuries (Cambridge: Cambridge University Press, 1967): 374-486.

D. Bulbeck, A. Reid, L. C. Tang, and Y. Wu (1998), Southeast Asian Exports Since the $14^{\text {th }}$ Century: Cloves, Pepper, Coffee and Sugar (Singapore: Institute of Southeast Asian Studies).

K. N. Chaudhuri (1985), Trade and Civilisation in the Indian Ocean: An Economic History from the Rise of Islam to 1750 (Cambridge: Cambridge University Press).

A. R. Disney (1978), Twilight of the Pepper Empire: Portuguese Trade in Southwest India in the Early Seventeenth Century (Cambridge, MA: Harvard University Press).

D. H. Fisher (1996), The Great Wave: Price Revolutions and the Rhythm of History (Oxford: Oxford University Press).

P. Friedman (2005), “Spices and Late-Medieval European Ideas of Scarcity and Value,” Speculum: A Journal of Medieval Studies 80 (October): 1209-27.

E. J. Hamilton (1934), American Treasure and the Price Revolution in Spain (Cambridge, Mass.: Harvard University Press).

Irwin, D.A. (1991), “Mercantilism as Strategic Trade Policy: The Anglo-Dutch Rivalry for the East India Trade,” Journal of Political Economy 99: 1296-1314.

W. Keller and C. H. Shiue (2004), "Markets in China and Europe on the Eve of the Industrial Revolution,” NBER Working Paper 10778, National Bureau of Economic Research, Cambridge, Mass. (September). 
J. Kieniewicz (1969), “The Portuguese Factory and Trade in Pepper in Malabar during the $16^{\text {th }}$ Century,” Indian Economic and Social History Review 6: 61-84.

F. C. Lane (1933), "Venetian Shipping During the Commercial Revolution,” American Historical Review 38, 2 (January): 219-239.

F. C. Lane (1940), “The Mediterranean Spice Trade: Further Evidence of Its Revival in the Sixteenth Century,” American Historical Review 45, 3 (April): 581-590.

F. C. Lane (1963), “Recent Studies on the Economic History of Venice,” Journal of Economic History 23, 3 (September): 312-334.

F. C. Lane (1968), “Pepper Prices before da Gama,” Journal of Economic History 28, 4 (December): 590-597.

A. H. Lybyer (1915), “The Ottoman Turks and the Routes of Oriental Trade,” English Historical Review XXX, CXX:577-588.

A. Maddison (2002), The World Economy: A Millennial Perspective (Paris: OECD).

V. Magalhães-Godinho (1953), “Le Repli Vénitien et Égyptien et la Route du Cap, 14961533," in Éventail de l'Histoire Vivante: Hommage à Lucien Febvre, Vol. I (Paris: Librarie Armand Colin): 283-300. Reprinted in M.N. Pearson (ed.), Spices in the Indian Ocean World (Gateshead: Variorum).

V. Magalhães-Godinho (1969), L'Économie de L'Empire Portugais aux XV et XVI Siècles (Paris: SEVPEN).

F. W. Mote (2003), Imperial China 900-1800 (Cambridge: Cambridge University Press). 
K. H. O’Rourke and J. G. Williamson (2002), “After Columbus: Explaining Europe’s Overseas Trade Boom, 1500-1800,” Journal of Economic History 62, 2 (June): 41756.

M. N. Pearson (1996), “Introduction,” in M.N. Pearson (ed.), Spices in the Indian Ocean World (Gateshead: Variorum).

J. R. S. Phillips (1998), The Medieval Expansion of Europe, $2^{\text {nd }}$ edition (Oxford: Clarendon Press).

A. Reid (1993), Southeast Asia in the Age of Commerce 1450-1680, Volume Two: Expansion and Crisis (New Haven: Yale University Press).

J. E. T. Rogers (1866-1902), A History of Agriculture and Prices in England: From the Year after the Oxford Parliament (1259) to the Commencement of the Continental War (1793) (Oxford: Clarendon Press).

P. Rozario (2005), Zheng He and the Treasure Fleet 1405-1433 (Singapore: SNP International).

C. R. de Silva (1988), “The Portuguese and the Trade in Cloves in Asia During the Sixteenth Century,” in Mohd Amin Hassan and Nik Hassan Shuhaimi Nik Abd Rahman (eds.), The Eighth Conference: International Association of Historians of Asia. Selected Papers (Selangor: Universiti Kebangsaan Malaysia), pp. 251-260. Reprinted in M. N. Pearson (ed.), Spices in the Indian Ocean World (Gateshead: Variorum 1996).

C. R. de Silva (1989), “The Portuguese Impact on the Production and Trade in Sri Lanka Cinnamon in Asia in the Sixteenth and Seventeenth Centuries,” Indica 26 (Bombay 1989): 25-38. Reprinted in M. N. Pearson (ed.), Spices in the Indian Ocean World (Gateshead: Variorum, 1996). 
P. Spufford (2003), Power and Profit: The Merchant in Medieval Europe (New York: Thames and Hudson).

N. Steensgaard (1973), The Asian Trade Revolution of the Seventeenth Century: The East India Companies and the Decline of the Caravan Trade (Chicago: University of Chicago Press).

J. de Vries (2003), “Connecting Europe and Asia: A Quantitative Analysis of the Cape-route Trade, 1497-1795,” in D. O. Flynn, A. Giraldez, and R. Von Glahn (eds.), Global Connections and Monetary History, 1470-1800 (Aldershot, U.K., 2003), pp. 35-106.

C. H. H. Wake (1979), “The Changing Pattern of Europe’s Pepper and Spice Imports, ca. 1400-1700,” Journal of European Economic History 8 (1979): 361-403.

H. van der Wee (1963), The Growth of the Antwerp Market and the European Economy (The Hague: Nijhoff).

J. E. Wills (1993), “Maritime Asia, 1500-1800: The Interactive Emergence of European Domination,” American Historical Review 98, 1 (February 1993): 83-105. 
Table 1. Time trends, nominal and real pepper prices

\begin{tabular}{|c|c|c|c|c|c|c|}
\hline \multicolumn{7}{|c|}{ Panel A. Pre-1503, nominal pepper prices } \\
\hline & Period & $\mathrm{N}$ & Coefficient & Std. Error & t-Statistic & Prob. \\
\hline England & $1401-1503$ & 103 & 0.0025 & 0.0010 & 2.39 & 0.019 \\
\hline Netherlands & $1450-1503$ & 54 & 0.0136 & 0.0023 & 5.99 & 0.000 \\
\hline Belgium & 1385-1503 & 119 & 0.0077 & 0.0008 & 9.45 & 0.000 \\
\hline Austria & 1444-1503 & 60 & 0.0182 & 0.0016 & 11.66 & 0.000 \\
\hline Cracow & 1389-1503 & 41 & -0.0021 & 0.0015 & -1.46 & 0.152 \\
\hline Navarre & 1358-1451 & 64 & 0.0110 & 0.0015 & 7.45 & 0.000 \\
\hline Venice & 1363-1503 & 141 & -0.0048 & 0.0006 & -7.82 & 0.000 \\
\hline \multicolumn{7}{|c|}{ Panel B. Pre-1503, real pepper prices } \\
\hline England & 1401-1503 & 103 & 0.0030 & 0.0012 & 2.54 & 0.012 \\
\hline Netherlands & $1450-1503$ & 54 & 0.0052 & 0.0035 & 1.47 & 0.148 \\
\hline Belgium & 1385-1503 & 119 & 0.0003 & 0.0010 & 0.27 & 0.785 \\
\hline Austria & 1444-1503 & 60 & 0.0117 & 0.0023 & 5.08 & 0.000 \\
\hline Navarre & 1358-1451 & 64 & 0.0000 & 0.0015 & -0.01 & 0.988 \\
\hline \multicolumn{7}{|c|}{ Panel C. Post-1503, nominal pepper prices } \\
\hline England & $1503-1582$ & 80 & 0.0132 & 0.0008 & 15.91 & 0.000 \\
\hline Netherlands & $1503-1600$ & 98 & 0.0034 & 0.0007 & 4.95 & 0.000 \\
\hline Belgium & $1503-1597$ & 95 & 0.0130 & 0.0006 & 21.96 & 0.000 \\
\hline Munich & $1524-1597$ & 74 & 0.0081 & 0.0006 & 12.63 & 0.000 \\
\hline Vienna & $1523-1604$ & 82 & 0.0065 & 0.0006 & 10.21 & 0.000 \\
\hline Austria & $1503-1609$ & 107 & 0.0060 & 0.0004 & 13.97 & 0.000 \\
\hline Cracow & $1503-1600$ & 73 & 0.0085 & 0.0006 & 14.42 & 0.000 \\
\hline Castile & $1518-1620$ & 103 & 0.0091 & 0.0005 & 19.46 & 0.000 \\
\hline Andalusia & $1555-1650$ & 92 & 0.0090 & 0.0008 & 10.92 & 0.000 \\
\hline New Castile & $1551-1620$ & 70 & 0.0091 & 0.0013 & 7.07 & 0.000 \\
\hline Valencia & $1504-1650$ & 147 & 0.0023 & 0.0003 & 6.98 & 0.000 \\
\hline Florence & $1520-1609$ & 90 & -0.0007 & 0.0010 & -0.70 & 0.488 \\
\hline Venice & $1503-1509$ & 7 & -0.0929 & 0.0219 & -4.24 & 0.008 \\
\hline \multicolumn{7}{|c|}{ Panel D. Post-1503, real pepper prices } \\
\hline England & 1503-1582 & 80 & -0.0070 & 0.0011 & -6.30 & 0.000 \\
\hline Netherlands & $1503-1600$ & 98 & -0.0153 & 0.0009 & -17.49 & 0.000 \\
\hline Belgium & $1503-1597$ & 95 & -0.0097 & 0.0010 & -9.44 & 0.000 \\
\hline Munich & $1524-1597$ & 74 & -0.0076 & 0.0015 & -5.09 & 0.000 \\
\hline Vienna & 1523-1589 & 67 & -0.0120 & 0.0019 & -6.44 & 0.000 \\
\hline Austria & $1503-1594$ & 92 & -0.0120 & 0.0016 & -7.59 & 0.000 \\
\hline Castile & $1518-1620$ & 103 & -0.0052 & 0.0010 & -5.30 & 0.000 \\
\hline Andalusia & $1555-1650$ & 92 & -0.0031 & 0.0018 & -1.72 & 0.088 \\
\hline New Castile & $1554-1620$ & 67 & -0.0080 & 0.0023 & -3.45 & 0.001 \\
\hline Valencia & $1504-1650$ & 147 & -0.0101 & 0.0005 & -20.13 & 0.000 \\
\hline Florence & $1520-1609$ & 90 & -0.0114 & 0.0019 & -6.02 & 0.000 \\
\hline
\end{tabular}

Notes: While it is not reported above, the pre-1503 regressions include a dummy for 14101414. $\mathrm{N}$ denotes number of observations in the regression. For all data sources, see the data appendix. 
Table 2. Time trends, real prices of fine spices and incense

\begin{tabular}{|c|c|c|c|c|c|c|}
\hline \multicolumn{7}{|c|}{ Panel A: Pre-1503 } \\
\hline & Period & $\mathrm{N}$ & Coefficient & Std. Error & t-Statistic & Prob. \\
\hline \multicolumn{7}{|l|}{ Cardamom } \\
\hline Navarre & 1358-1451 & 48 & 0.0079 & 0.0016 & 5.02 & 0.000 \\
\hline \multicolumn{7}{|l|}{ Cinnamon } \\
\hline England & $1431-1503$ & 73 & 0.0145 & 0.0024 & 5.94 & 0.000 \\
\hline Belgium & $1385-1503$ & 119 & 0.0022 & 0.0012 & 1.82 & 0.072 \\
\hline Austria & $1457-1503$ & 47 & 0.0228 & 0.0025 & 9.11 & 0.000 \\
\hline Navarre & $1358-1451$ & 62 & 0.0071 & 0.0014 & 5.19 & 0.000 \\
\hline \multicolumn{7}{|l|}{ Cloves } \\
\hline England & 1403-1503 & 101 & 0.0015 & 0.0015 & 0.98 & 0.331 \\
\hline Belgium & 1386-1503 & 118 & -0.0054 & 0.0011 & -4.72 & 0.000 \\
\hline Austria & $1442-1503$ & 62 & 0.0005 & 0.0021 & 0.25 & 0.803 \\
\hline Navarre & $1358-1451$ & 63 & -0.0042 & 0.0019 & -2.17 & 0.034 \\
\hline \multicolumn{7}{|l|}{ Ginger } \\
\hline England & 1406-1503 & 98 & -0.0037 & 0.0015 & -2.45 & 0.016 \\
\hline Belgium & $1385-1503$ & 119 & -0.0066 & 0.0011 & -5.95 & 0.000 \\
\hline Austria & $1442-1503$ & 62 & 0.0001 & 0.0018 & 0.05 & 0.960 \\
\hline Navarre & $1351-1451$ & 74 & 0.0017 & 0.0019 & 0.90 & 0.371 \\
\hline \multicolumn{7}{|l|}{ Mace } \\
\hline England & 1405-1503 & 99 & 0.0003 & 0.0014 & 0.18 & 0.859 \\
\hline \multicolumn{7}{|c|}{ Panel B: Post-1503 } \\
\hline \multicolumn{7}{|l|}{ Cinnamon } \\
\hline England & $1503-1576$ & 74 & -0.0069 & 0.0021 & -3.32 & 0.001 \\
\hline Belgium & $1503-1597$ & 95 & -0.0093 & 0.0017 & -5.49 & 0.000 \\
\hline Munich & $1524-1583$ & 60 & -0.0153 & 0.0040 & -3.79 & 0.000 \\
\hline Austria & $1503-1594$ & 92 & -0.0154 & 0.0016 & -9.37 & 0.000 \\
\hline Castile & $1503-1620$ & 118 & -0.0178 & 0.0010 & -17.61 & 0.000 \\
\hline Andalusia & $1554-1650$ & 96 & -0.0142 & 0.0024 & -5.92 & 0.000 \\
\hline New Castile & 1554-1619 & 66 & -0.0288 & 0.0027 & -10.54 & 0.000 \\
\hline \multicolumn{7}{|l|}{ Cloves } \\
\hline England & 1503-1576 & 74 & -0.0154 & 0.0021 & -7.30 & 0.000 \\
\hline Belgium & 1503-1598 & 96 & -0.0165 & 0.0011 & -14.51 & 0.000 \\
\hline Munich & 1524-1589 & 66 & -0.0084 & 0.0022 & -3.78 & 0.000 \\
\hline Austria & 1503-1594 & 92 & -0.0161 & 0.0017 & -9.30 & 0.000 \\
\hline Castile & $1503-1620$ & 118 & -0.0112 & 0.0012 & -9.51 & 0.000 \\
\hline Andalusia & $1569-1650$ & 80 & 0.0048 & 0.0023 & 2.05 & 0.044 \\
\hline \multicolumn{7}{|l|}{ Ginger } \\
\hline England & $1503-1576$ & 74 & -0.0032 & 0.0022 & -1.42 & 0.159 \\
\hline Belgium & $1503-1600$ & 98 & -0.0234 & 0.0018 & -13.12 & 0.000 \\
\hline Munich & $1524-1590$ & 67 & -0.0160 & 0.0023 & -7.08 & 0.000 \\
\hline Austria & 1503-1594 & 92 & -0.0116 & 0.0019 & -6.12 & 0.000 \\
\hline \multicolumn{7}{|l|}{ Incense } \\
\hline Castile & $1510-1620$ & 111 & -0.0055 & 0.0010 & -5.32 & 0.000 \\
\hline New Castile & $1554-1620$ & 67 & -0.0171 & 0.0019 & -9.23 & 0.000 \\
\hline \multicolumn{7}{|c|}{ Mace } \\
\hline England & $1503-1576$ & 74 & -0.0076 & 0.0017 & -4.43 & 0.000 \\
\hline
\end{tabular}

Notes: $\mathrm{N}$ denotes number of observations in the regression. The pre-1503 regressions include a dummy for 1410-14. For all data sources, see the data appendix. 
Table 3. Correlations in real pepper prices before and after 1503

(pairwise samples)

Panel A. Pre-1503

\begin{tabular}{lccccc}
\hline & England & Netherlands & Belgium & Austria & Navarre \\
\hline England & $\mathbf{1 . 0 0 0 0}$ & $\mathbf{0 . 4 9 7 6}$ & $\mathbf{0 . 5 5 8 3}$ & $\mathbf{0 . 2 9 4 0}$ & 0.2929 \\
Netherlands & $\mathbf{0 . 4 9 7 6}$ & $\mathbf{1 . 0 0 0 0}$ & $\mathbf{0 . 6 7 1 7}$ & $\mathbf{0 . 0 8 8 5}$ & N/A \\
Belgium & $\mathbf{0 . 5 5 8 3}$ & $\mathbf{0 . 6 7 1 7}$ & $\mathbf{1 . 0 0 0 0}$ & $\mathbf{0 . 3 2 3 0}$ & 0.3972 \\
Austria & $\mathbf{0 . 2 9 4 0}$ & $\mathbf{0 . 0 8 8 5}$ & $\mathbf{0 . 3 2 3 0}$ & $\mathbf{1 . 0 0 0 0}$ & N/A \\
Navarre & 0.2929 & N/A & 0.3972 & N/A & 1.0000 \\
\hline
\end{tabular}

Panel B. Post-1503

\begin{tabular}{lccccccccc}
\hline & England & Netherlands & Belgium & Austria & Vienna & Munich & Castile & Andalusia & New Castil \\
\hline England & $\mathbf{1 . 0 0 0 0}$ & $\mathbf{0 . 5 8 7 6}$ & $\mathbf{0 . 6 5 1 9}$ & $\mathbf{0 . 5 4 6 4}$ & 0.4421 & 0.4014 & 0.3533 & 0.6987 & 0.1429 \\
Netherlands & $\mathbf{0 . 5 8 7 6}$ & $\mathbf{1 . 0 0 0 0}$ & $\mathbf{0 . 6 7 4 4}$ & $\mathbf{0 . 6 2 6 5}$ & 0.5958 & 0.5489 & 0.5459 & 0.3670 & 0.2175 \\
Belgium & $\mathbf{0 . 6 5 1 9}$ & $\mathbf{0 . 6 7 4 4}$ & $\mathbf{1 . 0 0 0 0}$ & $\mathbf{0 . 5 0 6 2}$ & 0.5326 & 0.3911 & 0.4440 & 0.1681 & 0.0712 \\
Austria & $\mathbf{0 . 5 4 6 4}$ & $\mathbf{0 . 6 2 6 5}$ & $\mathbf{0 . 5 0 6 2}$ & $\mathbf{1 . 0 0 0 0}$ & 0.6395 & 0.4700 & 0.3716 & -0.6630 & -0.3758 \\
Vienna & 0.4421 & 0.5958 & 0.5326 & 0.6395 & 1.0000 & 0.7808 & 0.3239 & -0.0304 & 0.4657 \\
Munich & 0.4014 & 0.5489 & 0.3911 & 0.4700 & 0.7808 & 1.0000 & 0.4000 & 0.0181 & 0.3095 \\
Castile & 0.3533 & 0.5459 & 0.4440 & 0.3716 & 0.3239 & 0.4000 & 1.0000 & 0.3406 & 0.6058 \\
Andalusia & 0.6987 & 0.3670 & 0.1681 & -0.6630 & -0.0304 & 0.0181 & 0.3406 & 1.0000 & 0.4187 \\
New Castile & 0.1429 & 0.2175 & 0.0712 & -0.3758 & 0.4657 & 0.3095 & 0.6058 & 0.4187 & 1.0000 \\
Valencia & 0.4017 & 0.7871 & 0.5875 & 0.4270 & 0.6560 & 0.6160 & 0.5973 & 0.3858 & 0.5875 \\
Florence & 0.3939 & 0.3704 & 0.3904 & 0.3493 & 0.4494 & 0.5104 & 0.5057 & 0.2552 & 0.2496 \\
\hline
\end{tabular}

Note: see text and data appendix. 
Table 4. Correlations in real fine spice prices before and after 1503

(pairwise samples)

Panel A: Cloves

\begin{tabular}{lcccccc}
\hline \multicolumn{7}{c}{ Pre-1503 } \\
\hline England & England & Belgium & Austria & Navarre & & \\
Belgium & $\mathbf{1 . 0 0 0 0}$ & $\mathbf{0 . 4 1 0 5}$ & $\mathbf{- 0 . 0 7 9 9}$ & 0.4828 & & \\
Austria & $\mathbf{0 . 4 1 0 5}$ & $\mathbf{1 . 0 0 0 0}$ & $\mathbf{0 . 0 6 9 8}$ & 0.5925 & & \\
Navarre & $\mathbf{- 0 7 9 9}$ & $\mathbf{0 . 0 6 9 8}$ & $\mathbf{1 . 0 0 0 0}$ & -0.7663 & & \\
\hline \multicolumn{7}{c}{ Post-1503 } \\
\hline England & 0.4828 & 0.5925 & -0.7663 & 1.0000 & & \\
Belgium & England & Belgium & Austria & Munich & Castile & Andalusia \\
Austria & $\mathbf{1 . 0 0 0 0}$ & $\mathbf{0 . 7 3 2 1}$ & $\mathbf{0 . 6 9 1 5}$ & 0.5361 & 0.4831 & -0.5517 \\
Munich & $\mathbf{0 . 7 3 2 1}$ & $\mathbf{1 . 0 0 0 0}$ & $\mathbf{0 . 7 5 0 2}$ & 0.4385 & 0.6354 & -0.1609 \\
Castile & $\mathbf{0 . 6 9 1 5}$ & $\mathbf{0 . 7 5 0 2}$ & $\mathbf{1 . 0 0 0 0}$ & 0.6361 & 0.5461 & -0.5785 \\
Andalusia & 0.5361 & 0.4385 & 0.6361 & 1.0000 & 0.3650 & -0.2592 \\
\hline
\end{tabular}

Panel B: Cinnamon

\begin{tabular}{|c|c|c|c|c|c|c|c|}
\hline \multicolumn{8}{|c|}{ Pre-1503 } \\
\hline & England & Belgium & Austria & Navarre & & & \\
\hline England & 1.0000 & 0.3141 & -0.1145 & 0.0880 & & & \\
\hline Belgium & 0.3141 & 1.0000 & 0.4711 & 0.3355 & & & \\
\hline Austria & -0.1145 & 0.4711 & 1.0000 & $\mathrm{~N} \backslash \mathrm{A}$ & & & \\
\hline Navarre & 0.0880 & 0.3355 & $\mathrm{~N} \backslash \mathrm{A}$ & 1.0000 & & & \\
\hline \multicolumn{8}{|c|}{ Post-1503 } \\
\hline & England & Belgium & Austria & Munich & Castile & Andalusia & New Castile \\
\hline England & 1.0000 & 0.4817 & 0.4414 & 0.3609 & 0.1317 & 0.5801 & 0.3515 \\
\hline Belgium & 0.4817 & 1.0000 & 0.1905 & 0.7251 & 0.4823 & 0.7779 & 0.7733 \\
\hline Austria & 0.4414 & 0.1905 & 1.0000 & 0.1284 & 0.4787 & -0.5313 & -0.3526 \\
\hline Munich & 0.3609 & 0.7251 & 0.1284 & 1.0000 & 0.7287 & 0.7782 & 0.8456 \\
\hline Castile & 0.1317 & 0.4823 & 0.4787 & 0.7287 & 1.0000 & 0.9184 & 0.9453 \\
\hline Andalusia & 0.5801 & 0.7779 & -0.5313 & 0.7782 & 0.9184 & 1.0000 & 0.9057 \\
\hline New Castile & 0.3515 & 0.7733 & -0.3526 & 0.8456 & 0.9453 & 0.9057 & 1.0000 \\
\hline
\end{tabular}

\begin{tabular}{lcccc}
\multicolumn{5}{c}{ C. Ginger } \\
\hline \multicolumn{5}{c}{ Pre-1503 } \\
\hline England & Belgium & Austria & Navarre \\
\hline Belgium & $\mathbf{1 . 0 0 0 0}$ & $\mathbf{0 . 2 3 7 5}$ & $\mathbf{0 . 5 9 7 8}$ & 0.4443 \\
Austria & $\mathbf{0 . 2 3 7 5}$ & $\mathbf{1 . 0 0 0 0}$ & $\mathbf{0 . 2 4 2 6}$ & 0.6089 \\
Navarre & $\mathbf{0 . 5 9 7 8}$ & $\mathbf{0 . 2 4 2 6}$ & $\mathbf{1 . 0 0 0 0}$ & 0.9825 \\
\hline \multicolumn{5}{c}{ Post-1503 } \\
\hline England & 0.4443 & 0.6089 & 0.9825 & 1.0000 \\
\hline Belgium & England & Belgium & Austria & Munich \\
Austria & $\mathbf{1 . 0 0 0 0}$ & $\mathbf{0 . 0 1 7 0}$ & $\mathbf{0 . 0 3 9 6}$ & 0.6871 \\
Munich & $\mathbf{0 . 0 1 7 0}$ & $\mathbf{1 . 0 0 0 0}$ & $\mathbf{0 . 5 3 2 6}$ & 0.7564 \\
\hline & $\mathbf{0 . 0 3 9 6}$ & $\mathbf{0 . 5 3 2 6}$ & $\mathbf{1 . 0 0 0 0}$ & 0.2190 \\
& 0.6871 & 0.7564 & 0.2190 & 1.0000 \\
\hline
\end{tabular}

Note: see text and data appendix. 


\section{Data Appendix}

All price series used in this paper are denominated in different units and currencies (e.g, ducats per cargo or pence per pound). Thus, the analysis only explores time series within countries, where such measurement issues are irrelevant. When computing relative price trends within countries, however, we have made sure that the nominal prices being compared were expressed in the same currency.

For a good survey of the data sources, Arthur H. Cole and Ruth Crandall, "The International Scientific Committee on Price History,” Journal of Economic History 24, 3 (September 1964): 381-8 is still very useful. See also Fernand P. Braudel and Frank Spooner, 'Prices in Europe from 1450 to 1750,” Chapter VII, in E. E. Rich and C. H. Wilson (eds.), The Cambridge Economic History of Europe: Volume IV: The Economy of Expanding Europe in the Sixteenth and Seventeenth Centuries (Cambridge: Cambridge University Press, 1967): 374-486.

\section{Regional Price Data Sources:}

\section{Italy}

Venice 1363-1510 pepper prices from Frederic C. Lane, "Pepper Prices Before Da Gama," Journal of Economic History 28, 4 (December 1968): 590-7.

Bassano del Grappa 1501-1610 grain prices from Gabriele Lombardini, Pane e denaro a Bassano; prezzi del grano e politica dell'approvvigionamento dei cereali tra il 1501 e il 1799 (Venice: N. Pozza, 1963). Bassano del Grappa is an Italian town $60 \mathrm{~km}$. (37 mi.) inland from Venice.

Florence 1520-1610 pepper and grain prices from Giuseppe Parenti, Prime ricerche sulla rivoluzione dei prezzi in Firenze (Florence: C. Cya, 1939).

\section{$\underline{\text { Spain }}$}

All of the following but Barcelona and Navarre are from Earl J. Hamilton, American Treasure and the Price Revolution in Spain, 1501-1650 (Cambridge, Mass.: Harvard University Press, 1934):

\section{Andalusia 1554-1650 wheat and spice prices, 1555-1650 pepper prices.}

New Castile 1554-1620 wheat prices, 1551-1620 pepper and spice prices.

Old Castile 1503-1650 wheat prices, 1502-1620 spice prices, 1518-1620 pepper prices.

Valencia 1501-1650 wheat prices, 1504-1650 pepper and spice prices.

Barcelona 1463-1806 wheat prices, 1501-1808 barley prices, 1501-1800 spice prices, 15121802 pepper prices from Gaspar Feliu I Montfort, Precios y Salaries en la Cataluna Moderna: Volume I (Madrid: Banco de Espana, 1991).

Navarre 1351-1451 agricultural goods prices, 1358-1451 pepper prices, 1357-1451 spice prices from Earl J. Hamilton, Money, Prices and Wages in Valencia, Aragon, and Navarre, 1351-1500 (Cambridge, Mass.: Harvard University Press, 1936). 


\section{Holland}

1450-1800 rye, rye bread and pepper prices from Jan Luiten van Zanden, "What Happened to the Standard of Living before the Industrial Revolution? New Evidence from the Western Part of the Netherlands," in Robert Allen, Tommy Bengtson, and Martin Dribe (eds.), The Standard of Living before the Industrial Revolution (Oxford: Oxford University Press, 2005 forthcoming). Most of these price data were, in turn, taken from N. W. Posthumus, Inquiry into the History of Prices in Holland (Leiden: E. J. Brill, 1943/64) and a database of prices paid by the cloister of Leeuwenhorst between 1410 and 1570 .

\section{Belgium}

1366-1600 rye, barley oats and grain prices, 1385-1597 pepper prices, 1385-1600 spice prices from Herman van der Wee, The Growth of the Antwerp Market and the European Economy (fourteenth-sixteenth centuries): I. Statistics (Louvain: 1963).

\section{$\underline{\text { Austria }}$}

Vienna 1443-1594 wheat, barley, oats and grain prices, 1371-1609 pepper prices, 14421609 spice prices from Alfred Francis Pribram, Materialien zur Geschichte der Preise und Löhne in Österreich (Wien: Carl Ueberreuters Verlag, 1938). These data are from the records of Stift Klosterneuburg, which is roughly 15 miles outside of Vienna.

\section{Germany}

Munich 1450-1599 wheat, rye, barley, oats and grain prices, 1524-1599 pepper and spice prices from M. J. Elsas, Umriss Einer Geschichte der Preise und Lohne in Deutschland (Leiden: A.W. Sijthoff, 1936).

\section{England}

1401-1582 wheat, barley, oats, rye, and pepper prices, 1403-1582 spice prices from J. E. Thorold Rogers, A History of Agriculture and Prices in England : From the Year after the Oxford Parliament (1259) to the Commencement of the Continental War (1793): Vol. IV (Oxford: Clarendon Press, 1866-1902).

1200-1860 pepper prices from personal correspondence with Gregory Clark (2005).

1205-1865 grain prices from Gregory Clark, "The Condition of the Working-Class in England, 1200-2000: Magna Carta to Tony Blair,” unpublished, Department of Economics, University of California Davis (2004): Table 4, pp. 39-40.

\section{France}

1450-1600 grain prices from personal correspondence with Jan Luiten van Zanden (2005).

\section{Deflating by consumer price indices:}

We have consumer price indices for two countries, England and Belgium. In both cases the data were graciously provided by John Munro. For details on the methods used to calculate 
these CPI see, for example, his “Builders' Wages in Southern England and the Southern Low Countries, 1346 -1500: A Comparative Study of Trends in and Levels of Real Incomes,” in Simonetta Caviococchi, ed., L'Edilizia prima della rivoluzione industriale, secc. XIII-XVIII, Atti delle "Settimana di Studi" e altri convegni, no. 36, Istituto Internazionale di Storia Economica "Francesco Datini” (Florence, 2005), pp. 1013-76.

As can be seen in Appendix Figure 1, it makes no difference to our main results if we deflate pepper prices by the CPI, rather than by grain prices alone. The figure shows that CPIdeflated pepper prices experienced a sharp spike in the second decade of the $15^{\text {th }}$ century, but that abstracting from this, the deflated pepper price tended to trend upward during the $15^{\text {th }}$ century, before trending downward during the $16^{\text {th }}$ century. Thus, we feel confident that our grain-deflated results reported in the text do indeed reflect movements in real pepper prices. 



Appendix Figure 1. CPI-deflated pepper prices, England and Belgium

Source: see text. 

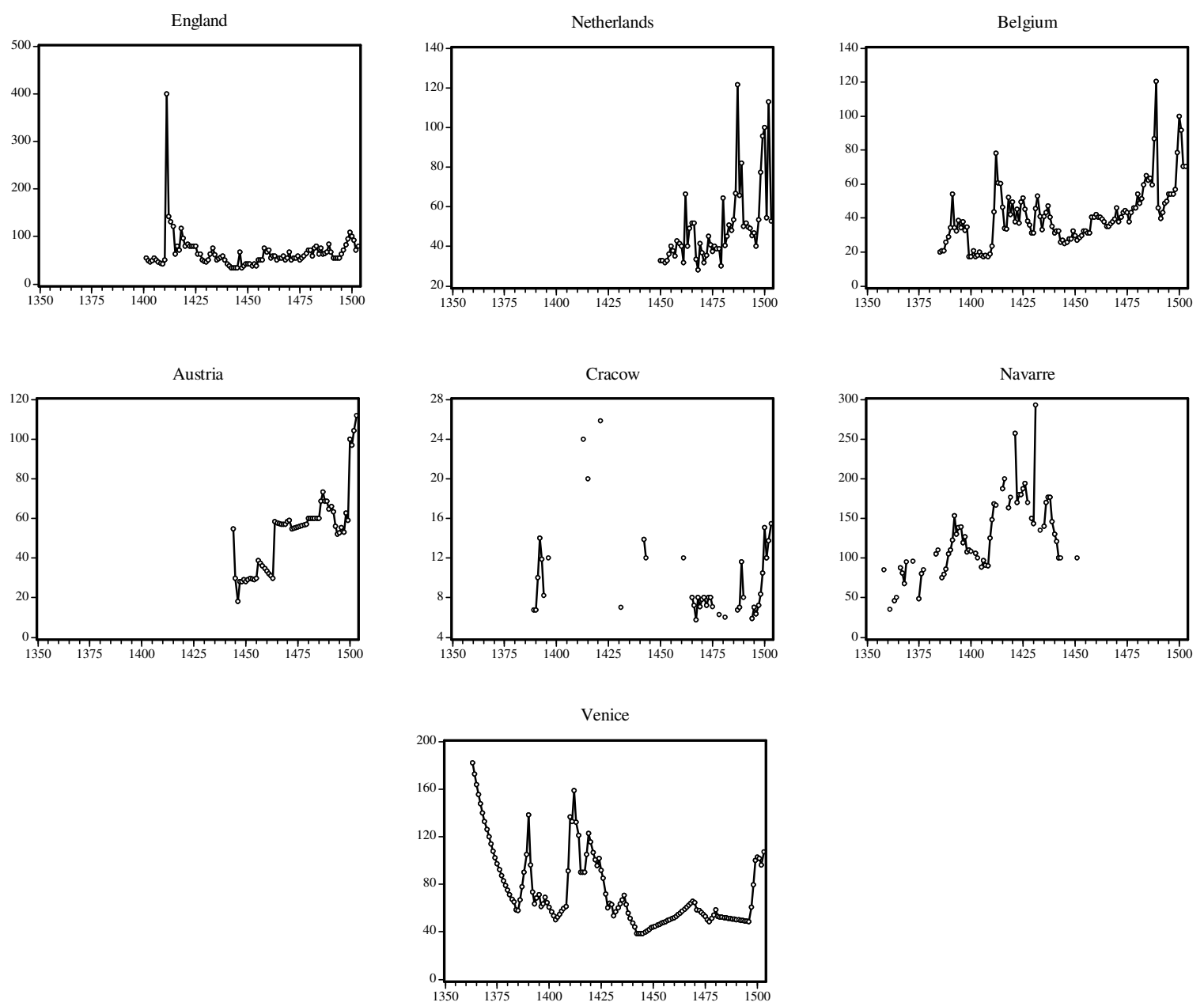

Figure 1. Nominal pepper prices, pre-1503

Source: see data appendix. 

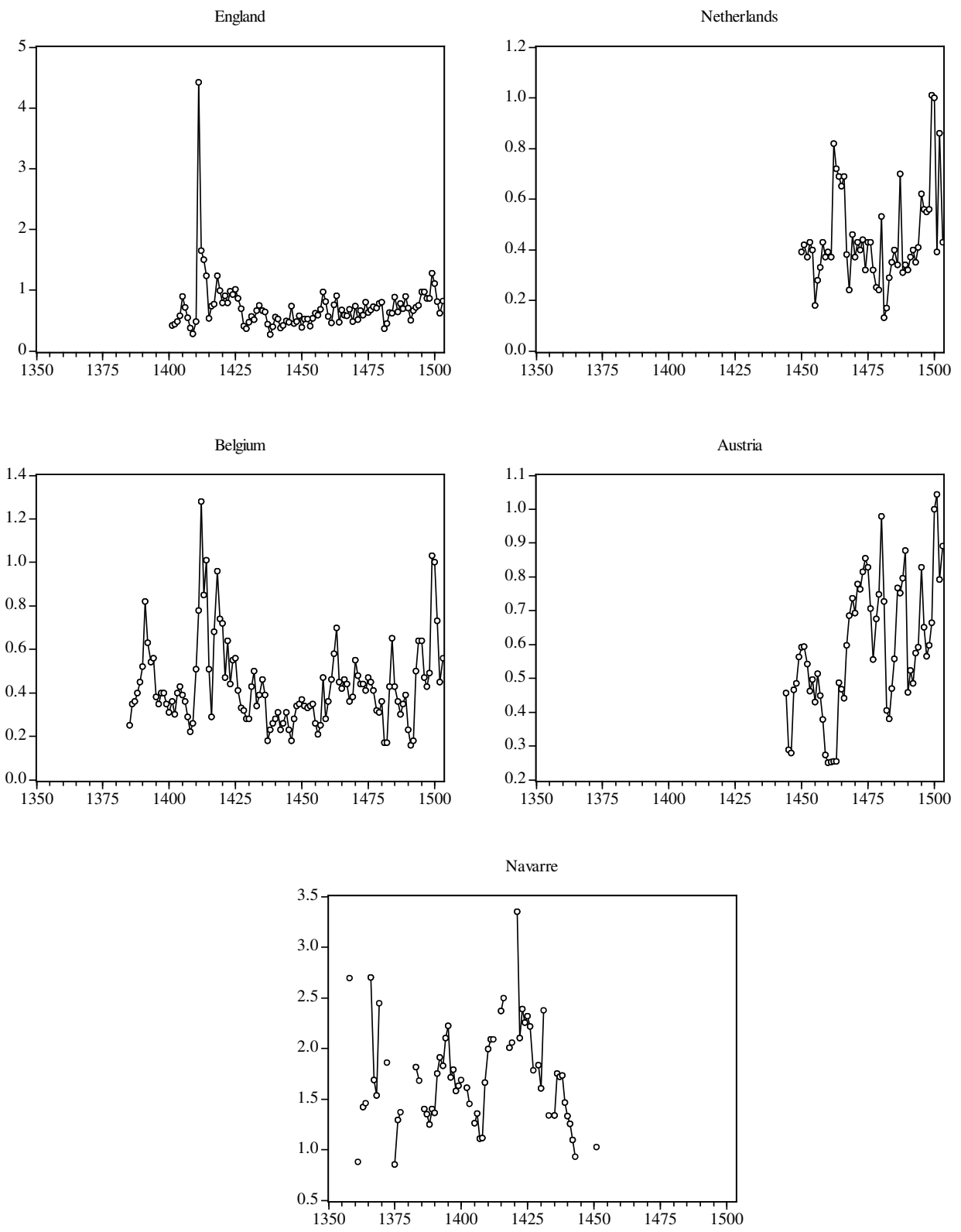

Figure 2. Real pepper prices, pre-1503

Source: see data appendix. 

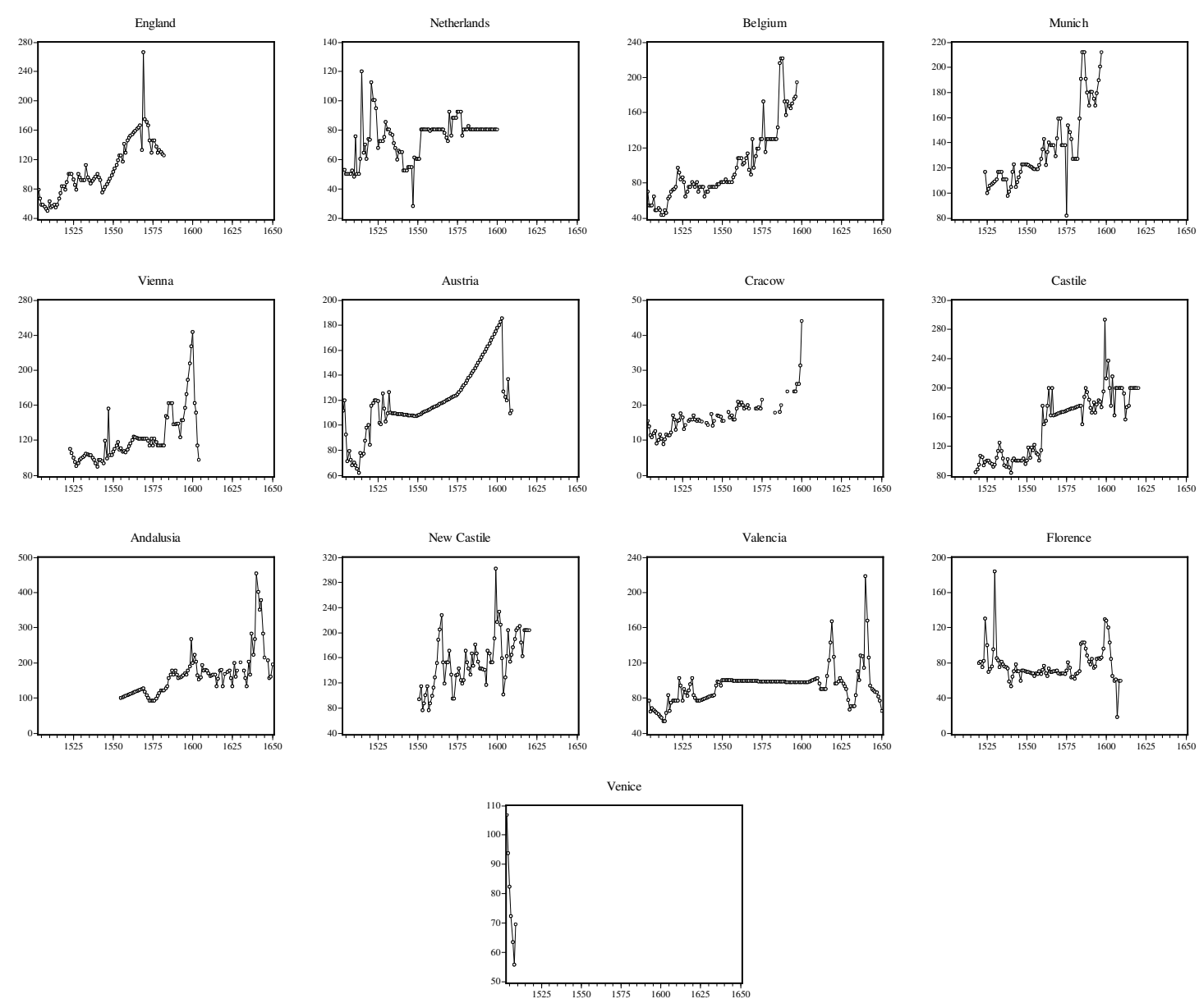

Figure 3. Nominal pepper prices, post-1503

Source: see data appendix. 

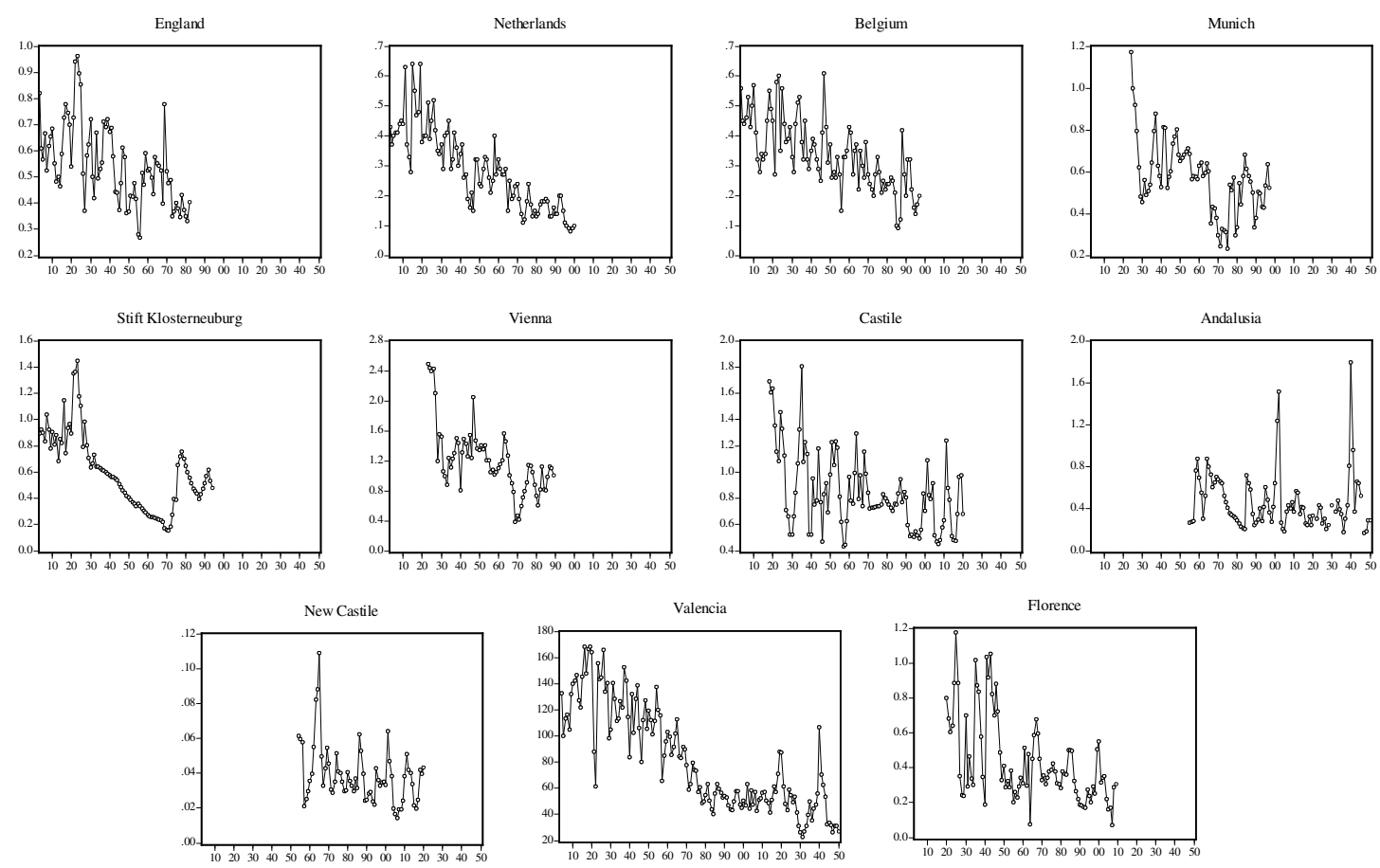

Figure 4. Real pepper prices, post-1503

Source: see data appendix. 


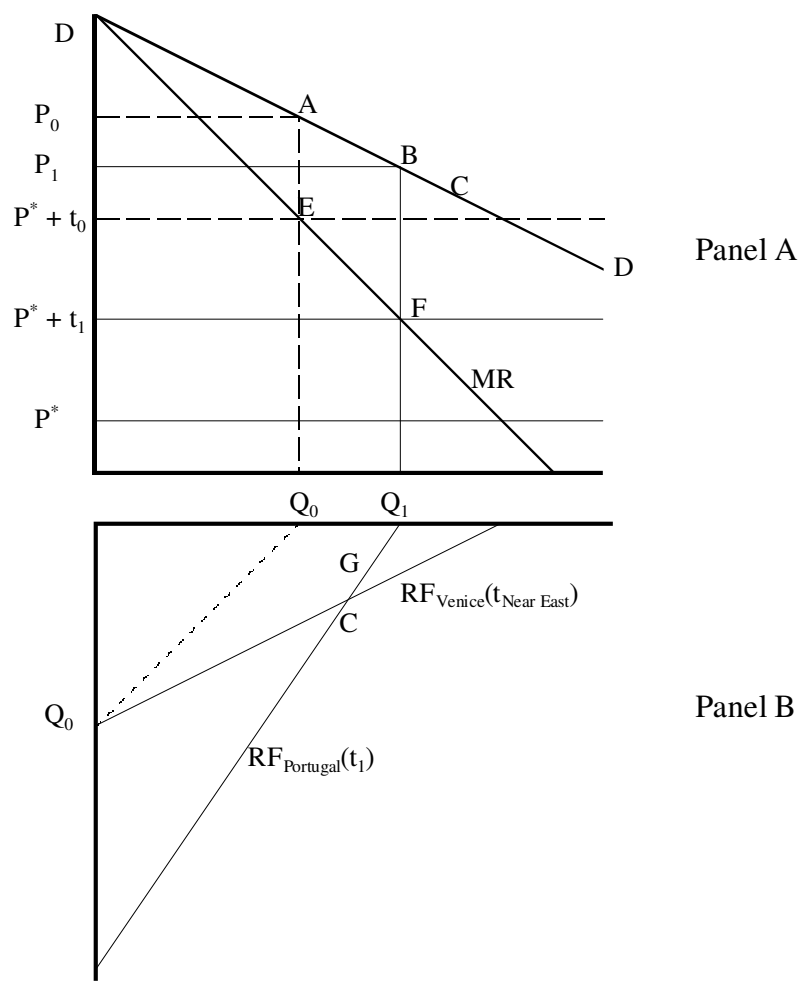

Figure 5. Monopoly, oligopoly and declining transport costs 